\title{
A Viability Theory for Digital Businesses: Exploring the Evolutionary Changes of Revenue Mechanisms to Support Managerial Decisions
}

Michaela Sprenger, University of St. Gallen, michaela.sprenger@unisg.ch Tobias Mettler, University of St. Gallen, tobias.mettler@unisg.ch Robert Winter, University of St. Gallen, robert.winter@unisg.ch

Citation: Sprenger M, Mettler T, Winter R. Information Systems Frontiers. DOI 10.1007/s10796-016$9638-x$

\begin{abstract}
The ongoing integration of Information Technology (IT) into various areas of our lives has led to a plethora of digital products and services. To survive competition in the long run, these offerings not only have to keep up with constant technological developments, but also have to adapt from a business point of view. Managers of these digital businesses have to especially focus on the design and evolution of their business' revenue mechanisms to ensure the viability of their offerings. The related decisions are not trivial, as managers have to be aware of the relevant contextual factors and have to react quickly to changes in the environment. This paper proposes a viability theory for digital businesses described by 17 propositions that may guide managers in the design of revenue mechanisms and thereby support the evolution as well as the viability of a digital business.
\end{abstract}

Keywords Digital business, Evolution, Managerial decision support, Revenue mechanisms, Viability theory. 


\section{Introduction}

Advances in technology such as the Internet's expansion into the real world and the fast decrease of network operation and communication costs have cleared the path for ingenious products and services (Zott et al. 2011; Timmers 1998; L.-d. Chen et al. 2002; Li et al. 2015). However, not only technological innovations radically changed the way how we purchase, consume, and dispose real and digital goods (Shaw 1999). In recent years, companies' efforts were focused on the business model, meaning how these products or services create, deliver, and capture value (Kishore and McLean 2002; McGrath 2010; Osterwalder et al. 2015; Teece 2010; Porra 2000). This was found to be of decisive importance as the business model is at the frontier of information systems enabling digital business and the related management aspects. It often correlates with superior firm performance (Williamson 2010; Koo et al. 2007) and thus can be considered as source of viable business practice (Lin et al. 2012; Oestreicher-Singer and Zalmanson 2013). As a consequence, in addition to the development of the digital business itself, there has likewise been a particularly strong emphasis on business model design and innovation for digital businesses, which led to a fast-paced and ever-changing business environment (Shaw 2000a, 2000b). Keeping the business viable in such an environment is not trivial and calls for guidance regarding the corresponding managerial decisions (Solaimani et al. 2015).

Building upon the seminal work by Demil \& Lecocq (2010), who call for more evolutionary considerations when studying business model design, we aim to shed some further light on the interplay between a digital business's evolution and its viability. More concretely, it is our goal to support managers regarding how they should evolve their digital business' revenue mechanisms - a prevalently discussed key component of a business model and its viability (Chesbrough 2010; Zott et al. 2011; Osterwalder and Pigneur 2010) - in order to survive competition in the long run. By means of a grounded theory approach we develop a viability theory, whereas we document our findings in form of propositions that should guide managers in the design of revenue mechanisms for their digital businesses. In this sense, we take up a stance on a transformational process in which business model components, such as revenue mechanisms, must be adjusted and fine-tuned over time for securing viability (Winter and Szulanski 2001).

Consequently, the article's contribution is twofold. On the one hand, our paper offers a rigorous approach to develop a viability theory for digital businesses which applies the main rational of the existing general viability theory (Aubin et al. 2011) and combines it with research on business model design. On the other hand, the paper has practical value as our theory aims at supporting managers in business model decisions by revealing important triggers for ensuring viability of digital businesses over time. Thereby, the viability theory for digital businesses prepares managers for potential changes in the environment and ultimately may guide business model design. 


\section{Related Work}

Viability is generally defined as the survival of a system or organization (Schwaninger 2006) and is the result of the development alongside the environment of reference (Golinelli et al. 2011). This concept is often linked to the viability theory introduced by Aubin et al. (2011), which deals with the dynamic adaptation of uncertain evolutionary systems to environments defined by constraints. According to Aubin et al. (2011), these evolutionary systems (e.g. each organization) can be described by variables whereas the evolution of these variables has a degree of uncertainty. The environment of such systems can be described by a set of constraints. Depending on the system of interest, the constraints can be e.g. biological, social, or economic ones. In an economic context, those constraints could be regulations that lead to certain rules a company must obey. For the overall system to be viable, each variable has to obey the constraints at any point in time.

Applying Aubin et al.'s general viability theory to the business context implies that an organization can only be viable - and ultimately survive - when it evolves according to the given constraints (Hedman and Kalling 2003). An abundance of literature has dealt with the evolution of businesses. For example, Nelson and Winter (1982) applied the concept of evolution to the business context in order to explain why some companies survive and others fail. In a broader sense, evolution is hereby understood as a non-stationary phenomenon (Fagerberg 2003) and explains the change in the conduct of business over time (Dosi and Nelson 1994). This adaption is usually triggered by decisions. Making decisions is one of the most crucial parts of management and can be defined as choosing among alternatives (Ford and Gioia 2000; March 1994). Hence, decisions initiate the business's adaption to opportunities, threats, or constraints and are closely linked to firm performance (Papadakis et al. 1998; Mitchell et al. 2011). Thereby, they are the precondition for viability. In this context, managerial decisions on the business's revenue mechanism - in Aubin et al.'s sense one of the variables describing the business as evolutionary system - play a significant role. Revenue mechanisms define the way a company makes money while providing value to the customer (Johnson et al. 2008; Osterwalder et al. 2005). According to Amit and Zott (2001), revenue mechanisms seem to be of special interest with regard to viability, since a company's survival depends not only on creating, but also on capturing value. Only when revenues are collected abundantly and continuously, businesses may generate sufficient profit to survive (Eurich et al. 2011; Chesbrough 2007; Teece 2010). Because revenue mechanisms have to be consistent with the external environment (Morris et al. 2005), managerial decisions regarding evolutionary changes are necessary preconditions for sustainable businesses (Hedman and Kalling 2003; Demil and Lecocq 2010). However, deciding upon viable revenue mechanisms that are in line with the context, i.e. the business's environment, is not trivial. As the environment is often characterized by a high level of complexity and dynamics, managerial decisions have to be taken with a degree of uncertainty (Vecchiato 2012). This uncertainty is seen as a key issue within managerial decisions and is especially relevant in fast changing market environments. 
The digital world, where products and services are bought and consumed online or on a technical device, is one prominent example for these fast-paced market environments (Clemons 2009). Digital businesses are able to perform fast changes when it comes to new product launches, the formation of business networks, or the management of customer relationships (Bharadwaj et al. 2013).

We focus our research on the digital world as we assume that evolutionary changes of businesses are expected to be of high importance in digital contexts. More specifically, our research interest concentrates on the digital businesses' revenue mechanisms and aims at better understanding how and under which conditions revenue mechanisms of digital products and services need to be evolved by managers in order to ensure the business's viability. Figure 1 illustrates the overall framework we plan to further develop in order to build a viability theory for digital businesses.

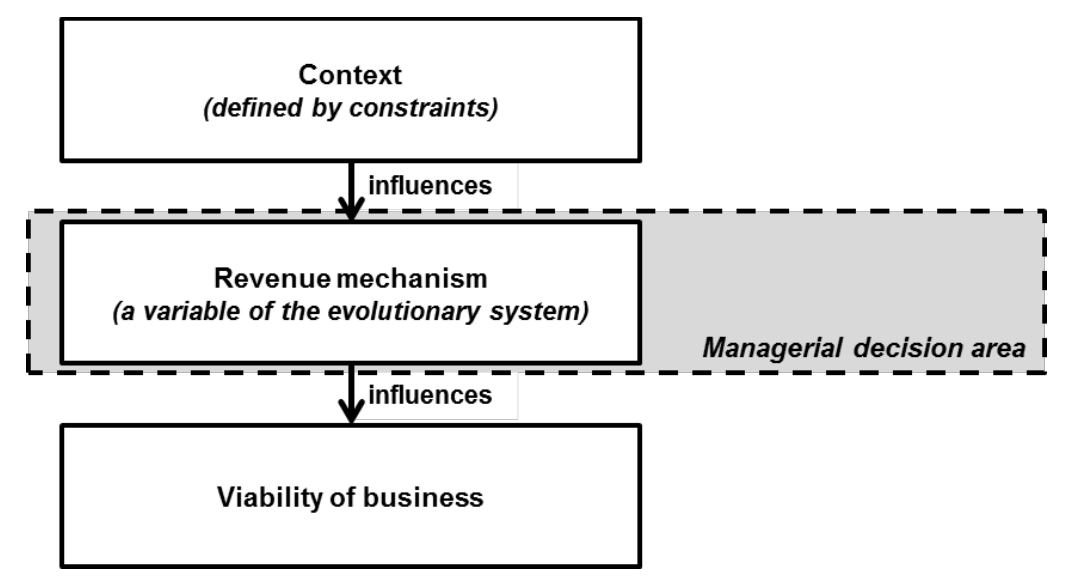

Figure 1 Overall framework for the viability theory of digital businesses

\section{$3 \quad$ Research Methodology}

Since there is already a large body of knowledge regarding digital goods and services we expected to find insights on revenue mechanisms in extant literature. Hence, we chose a literature review as overall research methodology. However, there is only little theoretical knowledge regarding the evolution of these revenue mechanisms over time. Therefore, we had to go further than just describing or understanding the knowledge of existing research and conducted a literature review that aimed at explaining under which conditions certain revenue mechanisms have a positive / negative impact on the viability of a digital business (Rowe 2014). The explaining nature of the literature review has the goal of theory building by defining the key concepts related to the digital business's viability, their interrelations, and corresponding recommendations (Okoli 2012). Since our theory building review interprets and codes existing literature to build up theoretical knowledge, it can be defined as a grounded theory literature review (Rowe 2014). This grounded theory literature review method was 
introduced by Wolfswinkel et al. (2013) who argue that this method not only guides a rigorous literature review but also fosters theory emergence. They enhanced the bibliographic approach proposed by Webster and Watson (2002) by applying key principles of grounded theory in the analysis of the selected literature. These key principles are based on the seminal work on grounded theory by Glaser and Strauss (1967) who introduced this method to derive theory in a systematical and rigorous manner from qualitative data. Grounded theory seeks to reveal relevant conditions, the respective actors, and their way of responding to these conditions (Corbin and Strauss 1990). This is consistent with our research interest, as we aim to better understand which constraints (relevant conditions) cause managers (respective actors) to change their business's revenue mechanisms for ensuring viability (response to conditions). We deemed this approach to be suitable for our study as there is a need for theory emergence regarding the evolution of revenue mechanisms for digital products and services and the related impact on a business's viability.

Following Urquhart et al. (2010), grounded theory is also an appropriate approach to embed and widen the scope of existing theories to the IS domain. Figure 2 describes how we employed grounded theory and how general viability theory inspired particularly the first phases of our research.

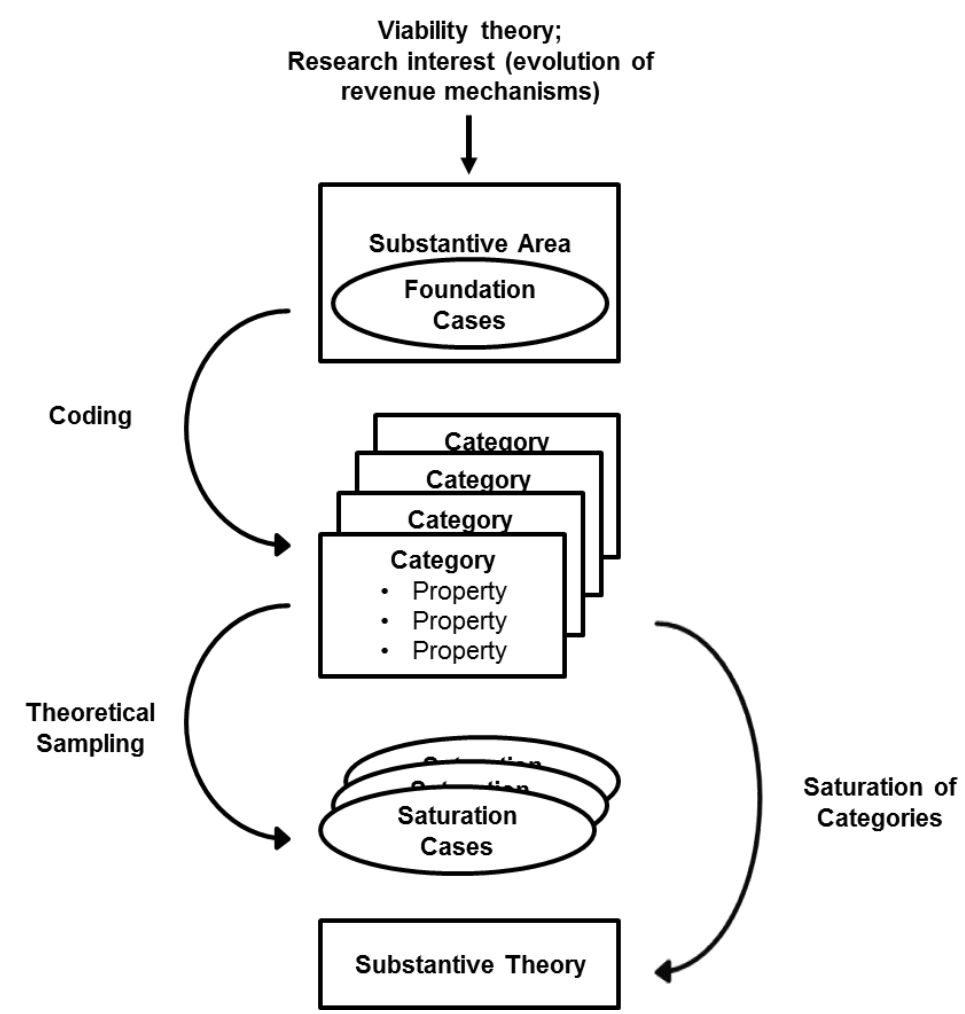

Figure 2 Grounded theory approach based on Lehmann (2001) 
In line with Wolfswinkel et al. (2013), we conducted an extensive literature review to obtain interesting cases and insights about revenue mechanisms and their evolutionary changes. We restricted our search scope to studies at the intersection between entrepreneurship, management, and IT that had a particular emphasis on digital businesses (Del Giudice and Straub 2011). At first, we searched EBSCO and ProQuest scientific databases to identify relevant foundation cases. Here, we iteratively performed searches using digital business model(s), e-business model(s), online business model(s), business model dynamic(s), business model innovation(s) and business model transformation(s) as search terms (without time period constraint) in the title, abstract, or keywords of the manuscript.

After this first search, we performed theoretical sampling, meaning that the data and the derived concepts and constructs defined the way in which data was further collected (Marshall 1996; Urquhart et al. 2010). Since almost half of the cases we identified in the first search iterations were published in IS-related journals we decided to concentrate our next search iterations with additional terms linked to business models, digital services, and revenue mechanisms on leading IS journals (Webster and Watson 2002), namely the European Journal of Information Systems, Information Systems Journal, Information Systems Research, Journal of AIS, Journal of Information Technology, Journal of MIS, Journal of Strategic Information Systems, and MIS Quarterly. Including all iterations in these IS journals our search included the terms business model(s), digital business(es), digital service(s), monetization, monetizing, online business(es), online service(s), revenue mechanism(s), revenue model(s), revenue stream(s), value capture, value capturing, and willingness to pay in title, abstract, or keywords (without time period constraint) of the manuscript.

Table 1 gives an overview of the relevant articles found per search term. We ended our iterations of category development and theoretical sampling after a saturation of our core categories was reached and a substantive theory could be formulated. The saturation criteria were met when categories were tightly linked to each other (Corbin and Strauss 1990).

\subsection{Inclusion Criteria}

Overall, the first search (including all iterations with six search terms in EBSCO and ProQuest scientific databases) led to 222 hits and the second search (including all iterations in leading IS journals with 13 search terms) added up 130 hits. The papers were judged to be relevant when their abstracts indicated that the study gave insights into revenue mechanisms of digital products or services. In case a judgment regarding the relevance for our research was not possible on the basis of the paper's abstract, we read the introduction, the discussion, and the conclusion in order to decide to include it to our case base or not. The judgment of papers and subsequent coding was performed by two researchers separately. Discrepancies were discussed until an agreement regarding the inclusion or exclusion was reached. At the end, 42 of the 352 papers were selected as our research basis. 
Table 1 Identified articles for the research basis by search term

\begin{tabular}{|c|c|c|c|c|c|c|c|c|c|c|c|c|c|c|c|}
\hline 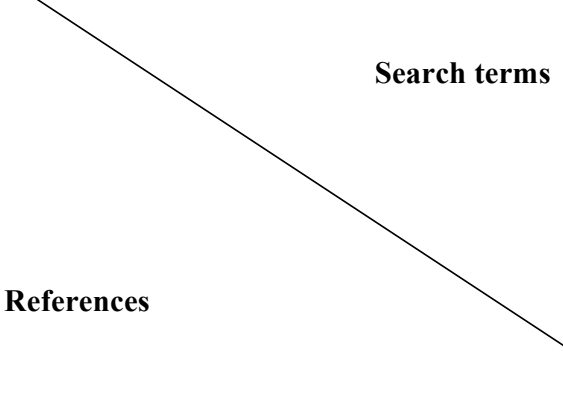 & 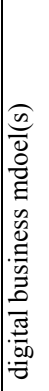 & 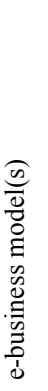 & 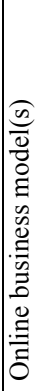 & 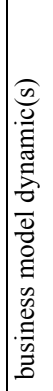 & 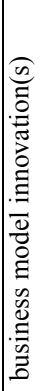 & 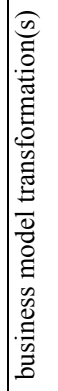 & 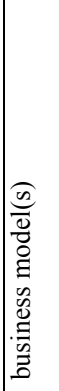 & 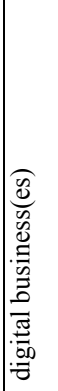 & 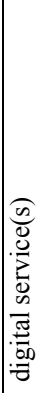 & 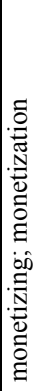 & 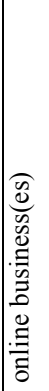 & 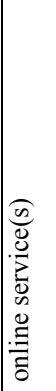 & 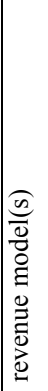 & 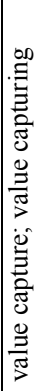 & 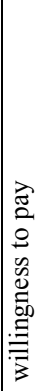 \\
\hline Amberg \& Schröder (2007) & & $\mathbf{x}$ & & & & & & & & & & & & & \\
\hline Amit \& Zott (2012) & & & & & $\mathbf{x}$ & & & & & & & & & & \\
\hline Bapna et al. (2009) & & & & & & & & & & & & $\mathbf{x}$ & & & \\
\hline Benghozi \& Lyubareva (2014) & & & $\mathbf{x}$ & & & & & & & & & & & & \\
\hline Berman et al. (2012) & & & & & $\mathbf{x}$ & & & & & & & & & & \\
\hline Bharadwaj (2013) & & & & & & & $\mathbf{x}$ & $\mathbf{x}$ & & & & & & $\mathbf{x}$ & \\
\hline Bhargava \& Sundaresan (2004) & & & & & & & $\mathbf{x}$ & & & & & & & & \\
\hline Bourreau et al. (2012) & $\mathbf{x}$ & & & & & & & & & & & & & & \\
\hline Brousseau \& Penard (2007) & $\mathbf{x}$ & & & & & & & & & & & & & & \\
\hline Bustinza et al.(2013) & & & $\mathbf{x}$ & & & & & & & & & & & & \\
\hline Casadesus-Masanell \& Hervas-Drane (2010) & & & $\mathbf{x}$ & & & & & & & & & & & & \\
\hline Casadesus-Masanell \& Zhu (2013) & & & & & $\mathbf{x}$ & & & & & & & & & & \\
\hline Casero-Ripollés \& Izquierdo-Castillo (2013) & & & $\mathbf{x}$ & & & & & & & & & & & & \\
\hline Chen \& Seshadri (2007) & & & & & & & & & & & & & & & $\mathbf{x}$ \\
\hline Clemons \& Madhani (2011) & & & & & & & $\mathbf{x}$ & $\mathbf{x}$ & & & $\mathbf{x}$ & & & & \\
\hline Clemons (2009) & & & & & & & $\mathbf{x}$ & & & $\mathbf{x}$ & $\mathbf{x}$ & & & & \\
\hline Concha et al. (2010) & & $\mathbf{x}$ & & & & & & & & & & & & & \\
\hline Currie (2004) & & $\mathbf{x}$ & & & & & & & & & & & & & \\
\hline Currie et al. (2007) & & $\mathbf{x}$ & & & & & & & & & & & & & \\
\hline Das et al. (2011) & & & & & & & $\mathbf{x}$ & & & & & & & & \\
\hline Deodhar et al. (2012) & & & & & & & $\mathbf{x}$ & & & & & & & & \\
\hline Desai \& Currie (2005) & & $\mathbf{x}$ & & & & & & & & & & & & & \\
\hline Dewan et al. (2003) & & & & & & & $\mathbf{x}$ & & & & & & & & \\
\hline Feng et al. (2009) & & & & & & & & & & & $\mathbf{x}$ & & & & \\
\hline Günzel \& Holm (2013) & & & & & $\mathbf{x}$ & & & & & & & & & & \\
\hline Hinz \& Spann (2008) & & & & & & & $\mathbf{x}$ & & & & & & & & \\
\hline Hinz et al. (2011) & & & & & & & & & & & & & & & $\mathbf{x}$ \\
\hline Hu et al. (2004) & & & & & & & $\mathbf{x}$ & & & & & & & & \\
\hline Kerrigan \& Graham (2010) & & & $\mathbf{x}$ & & & & & & & & & & & & \\
\hline Khanagha et al. (2014) & & & & & $\mathbf{x}$ & & & & & & & & & & \\
\hline Kim \& Ahn (2007) & & $\mathbf{x}$ & & & & & & & & & & & & & \\
\hline Krishnan et al. (2007) & $\mathbf{x}$ & & & & & & & & & & & & & & \\
\hline Krueger \& Swatman (2004) & & $\mathbf{x}$ & $\mathbf{x}$ & & & & & & & & & & & & \\
\hline Laffey (2010) & & $\mathbf{x}$ & & & & & & & & & & & & & \\
\hline Lin et al. (2011) & & & & & & & & & & & & & & & $\mathbf{x}$ \\
\hline Lin et al. (2012) & & & & & & & $\mathbf{x}$ & & & $\mathbf{x}$ & & $\mathbf{x}$ & $\mathbf{x}$ & & \\
\hline Liu et al. (2010) & & & & & & & & & & & & & & & $\mathbf{x}$ \\
\hline Oestreicher-Singer \& Zalmanson (2013) & & & & & & & $\mathbf{x}$ & $\mathbf{x}$ & & & & & & $\mathbf{x}$ & $\mathbf{x}$ \\
\hline Papies et al. (2011) & & & $\mathbf{x}$ & & & & & & & & & & & & \\
\hline Roquilly (2011) & & & & & & & $\mathbf{x}$ & & & & & & & & \\
\hline Williams et al. (2008) & & & & & & & & & $\mathbf{x}$ & & & & & & \\
\hline Wu \& Banker (2010) & & & & & & & & & & & & & & & $\mathbf{x}$ \\
\hline
\end{tabular}

Note: The terms revenue mechanism(s) and revenue stream(s) yielded no relevant hits and are therefore not listed. 


\subsection{Method of Analysis}

Data collection and analysis in grounded theory are interrelated processes (Corbin and Strauss 1990). In order to perform data collection, coding, and comparison to identified constructs in a joint and ongoing manner, we proceeded as follows. Our research interest as well as Aubin et al.'s (2011) viability theory provided us with the first provisional categories that we already illustrated in Figure 1: context, revenue mechanisms, and viability. We analyzed our case base to verify if these categories were really relevant for our theory and to discover which properties are included in each category. For example, we were interested which kind of revenue mechanisms are instantiated in the described cases and which kind of contexts were influencing the managerial decisions regarding these mechanisms. Special emphasis was given to find clues in the literature that described how companies managed the evolution of revenue mechanisms in changing contexts. Moreover, the papers were also examined regarding any other relevant category and the related properties that might enhance our theory. These categories were captured in an iterative manner of open coding to generate higher-abstraction level categories, axial coding to relate the categories to their respective properties, and selective coding to develop and refine the relation between the different categories (Wolfswinkel et al. 2013).

\section{$4 \quad$ Analysis and Findings: The Viability Theory for Digital Businesses}

This section documents the insights from the grounded theory approach. Because it is difficult to encompass the entire extracted knowledge within a limited amount of pages, the following paragraphs emphasize the description of the theory itself and only present insights into the theory building process when it enhances the reader's understanding (cf. Appendix for further details).

As stated in the beginning, viability is influenced by the revenue mechanisms. Since the revenue mechanisms describe the way of value capturing, they determine if and to what extend the business is profitable. Only when revenue mechanisms are designed to attract and retain customers as well as to leverage this customer base, the business can be viable. These revenue mechanisms are subject to managerial decisions: Managers can actively choose and decide which revenue mechanisms should be implemented for their products and services.

But, even though revenue mechanisms can be designed by businesses, they have to fit to the environment the business is operating in. In contrast to the design of revenue mechanisms, the manager has often no or only limited control over the context. Hence, the managerial decisions regarding revenue mechanisms have to be aligned with the context to have the desired effect on the business's viability. While reading the literature and coding the identified cases we found that the category context needed to be split up in the categories constraints, type of digital offering, and stage of evolution. 
Constraints influence the revenue mechanisms - and as a consequence the related managerial decisions - directly. This is consistent with the viability theory of Aubin et al. (2011) as a variable (in our case the revenue mechanism) can evolve in a non-deterministic way as long as it considers the constraints. However, revenue mechanisms are not only directly influenced by constraints, but also indirectly by the two other context categories type of digital offering and stage of evolution. The type of digital offering is of importance, since revenue mechanisms cannot meaningfully be examined without a reference to the corresponding product or service. This is consistent with the extant literature, which states that revenue mechanisms are always linked to the offering, i.e. a product or service (Hedman and Kalling 2003; Osterwalder 2004). Our analysis revealed that the type of digital offering has a direct effect on which constraints are relevant for the design of revenue mechanisms. Additionally, our analysis suggested the business's stage of evolution to be an important category in our theory as our cases disclosed that the constraints for suitable revenue mechanisms have to be linked to time. In this context, time is understood as an evolutionary stage of the business, which is also consistent with our research interest to understand the evolution of revenue mechanisms. Table 2 gives an overview of all relevant categories and properties found in our literature base as well as short explanations.

Table 2 Categories and properties for theory building

\begin{tabular}{|c|c|c|}
\hline $\begin{array}{l}\text { Cate- } \\
\text { gory }\end{array}$ & Property & Explanation \\
\hline \multirow{4}{*}{ 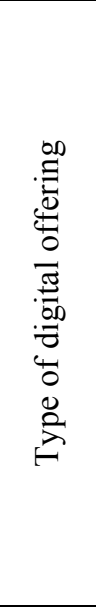 } & Brokerage & $\begin{array}{l}\text { Brokerage services are offered by an intermediary. Examples are providers of e- } \\
\text { marketplaces or online stores for digital products / services (Williams et al. 2008; Feng } \\
\text { et al. 2009). Search engines like Google are also a form of brokerage service. In this } \\
\text { case, the intermediary performs a matching service between the advertisers and } \\
\text { potential buyers, i.e. the searchers (Clemons and Madhani 2011; Liu et al. 2010). }\end{array}$ \\
\hline & Content & $\begin{array}{l}\text { This type of offering relates to businesses which provide digital content, e.g. music } \\
\text { (Papies et al. 2011; Bustinza et al. 2013) and news media (Günzel and Holm 2013; } \\
\text { Casero-Ripollés and Izquierdo-Castillo 2013). }\end{array}$ \\
\hline & Experience & $\begin{array}{l}\text { Providing experience and enjoyment to customers can be the core of a digital offering. } \\
\text { Examples are social networking sites (Williams et al. 2008; Wu and Banker 2010), } \\
\text { virtual worlds, or online games (Roquilly 2011; Hinz et al. 2011). }\end{array}$ \\
\hline & $\begin{array}{l}\text { Software / } \\
\text { Computing }\end{array}$ & $\begin{array}{l}\text { Businesses providing software, e.g. in form of applications that can be used as a } \\
\text { service (Khanagha et al. 2014; Currie 2004; Concha et al. 2010), or computing } \\
\text { products / services, e.g. online storage grids (Bapna et al. 2009), belong to this type of } \\
\text { digital offering. }\end{array}$ \\
\hline \multirow{2}{*}{ 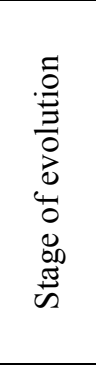 } & Early stage & $\begin{array}{l}\text { A business can be in an early stage when the business was just transferred from an } \\
\text { offline to an online version, as in the case of music or news media, or it can be a } \\
\text { business that was purely invented for the digital world, e.g. Internet search engines. } \\
\text { This stage is mainly characterized by the fact that an online customer base has yet to } \\
\text { be built. }\end{array}$ \\
\hline & Mature stage & $\begin{array}{l}\text { In the mature stage, the business not only persists for a longer period of time in the } \\
\text { digital world, but has also managed to attract a solid customer base. The business } \\
\text { model in a mature stage has to be designed in such a way, that the business retains its } \\
\text { customer base while at the same time making enough money to stay viable. }\end{array}$ \\
\hline 苍 & $\begin{array}{l}\text { Ability to } \\
\text { adopt new } \\
\text { revenue } \\
\text { mechanisms }\end{array}$ & $\begin{array}{l}\text { In order to adopt a certain revenue mechanism the provider needs the ability to do so. } \\
\text { Often the ability is restricted by technological factors, e.g. in order to be able to charge } \\
\text { on the basis of usage, the usage has to be measurable (Concha et al. 2010). }\end{array}$ \\
\hline
\end{tabular}




\begin{tabular}{|c|c|c|}
\hline $\begin{array}{l}\text { Cate- } \\
\text { gory }\end{array}$ & Property & Explanation \\
\hline & $\begin{array}{l}\text { Differen- } \\
\text { tiation } \\
\text { capabilities }\end{array}$ & $\begin{array}{l}\text { The capability to differentiate the product / service from (free) alternatives in the } \\
\text { market increases customers' willingness to pay and alleviates the constraints on the } \\
\text { choice of revenue mechanisms (Kerrigan and Graham 2010). }\end{array}$ \\
\hline & $\begin{array}{l}\text { Free offer- } \\
\text { ings in the } \\
\text { market }\end{array}$ & $\begin{array}{l}\text { When a comparable product / service is offered for free in the market, customers } \\
\text { become reluctant to pay which restricts the choice of adequate revenue mechanisms } \\
\text { (Casero-Ripollés and Izquierdo-Castillo 2013). }\end{array}$ \\
\hline & $\begin{array}{l}\text { Information } \\
\text { asymmetry }\end{array}$ & $\begin{array}{l}\text { Information asymmetry, meaning that one party (e.g. the customer) has more } \\
\text { knowledge than the other party (e.g. the provider), can take on different forms. This is } \\
\text { for example the case when a provider faces uncertain customer demands (Das et al. } \\
\text { 2011). }\end{array}$ \\
\hline & Lock-in & $\begin{array}{l}\text { When customers bear high switching costs they are less likely to turn to a competing } \\
\text { product / service. This phenomenon is called lock-in. A lock-in effect can occur due to } \\
\text { high upfront investments, habits, appreciation, or even addiction (Roquilly } 2011 ; \mathrm{Wu} \\
\text { and Banker 2010; Bhargava and Sundaresan 2004). }\end{array}$ \\
\hline & $\begin{array}{l}\text { Willingness } \\
\text { to pay }\end{array}$ & $\begin{array}{l}\text { Customer's willingness to pay reflects the money they are willing to spend for the } \\
\text { product / service offered. With regard to digital offerings, customers often have a low } \\
\text { willingness to pay (Krueger and Swatman 2004; Laffey 2010). }\end{array}$ \\
\hline \multirow{6}{*}{ 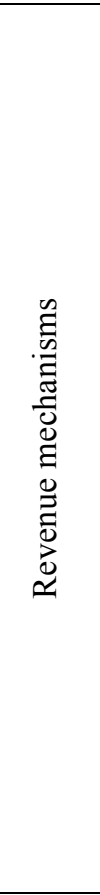 } & Advertising & $\begin{array}{l}\text { Advertising is a typical revenue mechanism used in a multi-sided or third-party payer } \\
\text { environment: the provider offers the service to the users for free, whereas a third party } \\
\text { - here the advertiser - pays for participation (Clemons and Madhani 2011; Bharadwaj } \\
\text { et al. 2013). A related form of the advertising revenue mechanism is selling user data } \\
\text { to advertisers (Williams et al. 2008). }\end{array}$ \\
\hline & $\begin{array}{l}\text { Brokerage } \\
\text { fees }\end{array}$ & $\begin{array}{l}\text { Brokerage fees are used in multisided businesses where an intermediary offers a } \\
\text { matching function between buyers and sellers (Laffey 2010). The intermediary's } \\
\text { revenue can be generated through various mechanisms: Often a fee per transaction, } \\
\text { respectively a commission, is charged (Kim and Ahn 2007; Deodhar et al. 2012) or, as } \\
\text { presented by Lin et al. (2011), an intermediary can charge an access fee both from } \\
\text { sellers and buyers. }\end{array}$ \\
\hline & Freemium & $\begin{array}{l}\text { With a freemium revenue mechanism basic services are offered for free and providers } \\
\text { charge for additional premium services (Oestreicher-Singer and Zalmanson 2013). }\end{array}$ \\
\hline & Pay-per-use & $\begin{array}{l}\text { With a pay-per-use revenue mechanism, customers only pay for the amount they } \\
\text { actually use, whereas the usage can be measured in various ways, e.g. based on } \\
\text { number of users, periods of time, etc. (Concha et al. 2010). }\end{array}$ \\
\hline & Purchase & $\begin{array}{l}\text { The most classic revenue mechanism is the common purchase, where a product or } \\
\text { service is offered for money. A prominent example is iTunes, where each song can be } \\
\text { bought for a micropayment (Bustinza et al. 2013; Papies et al. 2011). }\end{array}$ \\
\hline & Subscription & $\begin{array}{l}\text { With subscription (or fees per term), revenue is created through users' periodic } \\
\text { payments or fixed installments such as a membership fee (Amberg and Schröder 2007; } \\
\text { Krishnan et al. 2007). }\end{array}$ \\
\hline \multirow{2}{*}{ 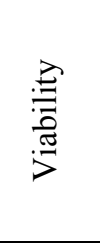 } & $\begin{array}{l}\text { Viability } \\
\text { enhancing }\end{array}$ & $\begin{array}{l}\text { As businesses need to capture value in order to be viable and survive, viability is } \\
\text { supported whenever revenue is increased. This can be achieved by an increase in } \\
\text { (paying) customers or by higher revenues per customer. }\end{array}$ \\
\hline & $\begin{array}{l}\text { Viability } \\
\text { reducing }\end{array}$ & $\begin{array}{l}\text { Viability is reduced when a business is less likely to capture enough value to survive. } \\
\text { Reasons can be a decrease in (paying) customers or a decline in revenues per } \\
\text { customer. }\end{array}$ \\
\hline
\end{tabular}

Based on the categories and properties identified in our cases, the overall framework of the viability theory (which was depicted in Figure 1) could be further developed: Figure 3 provides an overview of the viability theory for digital businesses by illustrating the interrelations of the categories type of digital offering, stage of evolution, constraints, revenue mechanisms, and viability. 


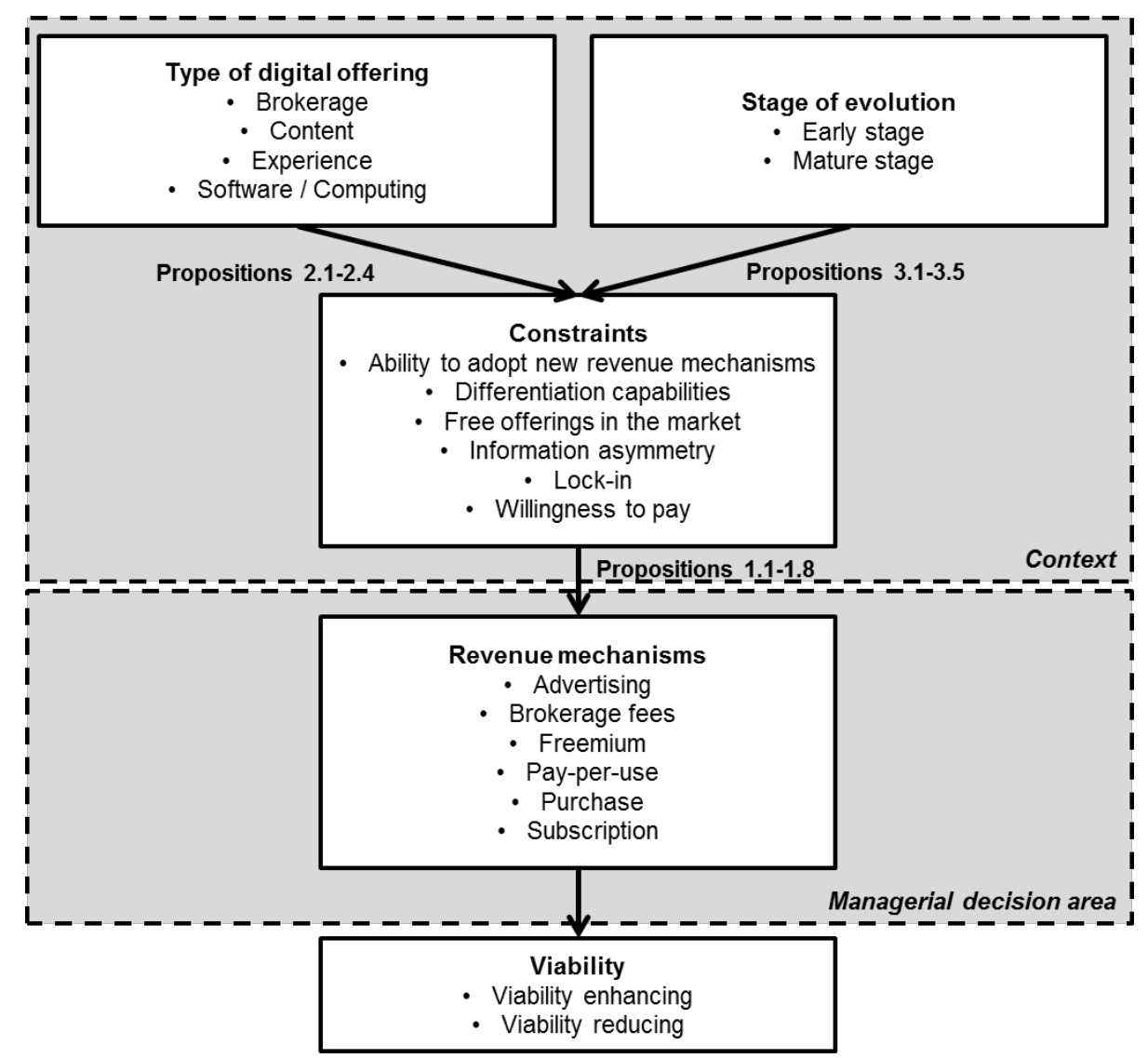

Figure 3 Viability theory for digital businesses

Our theory is built by means of a set of propositions which shed light on the questions which revenue mechanisms seem to be viable when certain constraints are present (direct influence) and how the business's stage of evolution and its type of digital offering seem to influence the set of viable revenue mechanisms (indirect influence). These propositions are always a recommendation which revenue mechanism to choose in which context, as revenue mechanisms are the construct which can be actively designed and decided upon by managers.

The propositions, on the one hand, give guidance about viable decisions when designing a company's business model. On the other hand, they indicate different conditions where distinct revenue mechanisms are more suitable than others. Hence, the propositions help align the managerial decisions with the given context. This mitigates decision uncertainty as it is usually not necessary to predict the future but to prepare managers regarding possible future scenarios (Vecchiato 2012). Thereby, the propositions not only support managers in choosing revenue mechanisms under the given conditions but also prepare them for potential changes in the environment. 


\subsection{The Direct Influence of Constraints on Revenue Mechanisms}

According to the general viability theory (Aubin et al. 2011), constraints govern the evolutionary development of a system with all its variables. For our research, this means that the identified constraints (i.e. ability to adopt new revenue mechanisms, differentiation capabilities, free offerings in the market, information asymmetry, lock-in, and willingness to pay) may determine the appropriateness of a revenue mechanism.

Since our primary objective is to give guidance regarding when to choose which revenue mechanism, we will further elaborate on this interrelation.

Overall, when thinking about which revenue mechanism to choose, there is always the question if the business has the ability to select a certain revenue mechanism. First of all, the intended revenue mechanism has to be technically feasible, e.g. for a revenue model based on usage, the usage has to be measurable (Concha et al. 2010). Besides technical constraints, there are also organizational aspects to consider when it comes to the ability to opt for certain revenue mechanisms: The revenue mechanisms have to be consistent with the overall business. For example, Krueger and Swatman (2004) report on a case where an online newspaper refrained from adopting an advertising revenue stream where it would have had to sell customer data, as this was not consistent with its image and reputation.

Proposition 1.1: Only when there is a fit with the technical ability as well as with organizational aspects, choose the envisioned revenue mechanism.

In addition to the ability to adopt a revenue mechanism, also the customers' willingness to pay can be a constraining factor. When customers appreciate the offering and its value they are more likely to invest money. In case customers have a high willingness to pay, businesses can charge them directly: Purchase, subscription, and pay-per-use are viable options (Wu and Banker 2010; Roquilly 2011; Oestreicher-Singer and Zalmanson 2013).

Proposition 1.2: When customers' willingness to pay is high, choose revenue mechanisms that charge the customer directly (e.g. subscription).

The customers' high willingness to pay might be linked to the existence of a lock-in effect. A lock-in occurs when customers are less likely to turn to a competing product or service, as they would bear high switching costs. These high switching costs can be attributed to high upfront investment costs or the mere appreciation of the product or service (Bhargava and Sundaresan 2004; Clemons 2009).

Proposition 1.3: In presence of a lock-in effect, choose revenue mechanisms that charge the customer directly (e.g. subscription). 
However, digital offerings often face customers with a low willingness to pay. When the willingness to pay is low or even zero, meaning that customers are not willing to pay at all, the customer cannot be charged directly. As long as the product or service is not offered for free, customers would be unwilling to participate or would search for an illegal way to acquire the service for free (Papies et al. 2011).

Proposition 1.4: When customers' willingness to pay is (extremely) low, chose revenue mechanisms that charge the customer indirectly (e.g. advertising).

One reason for customers' low willingness to pay is information asymmetry. For example, on emarketplaces the anonymity gives sellers the possibility to act under false identities, so that they can easily commit fraud by selling products with a lower quality level which is not revealed until the buyer already paid (Hu et al. 2004). This information asymmetry can lead to a lack of trust on the buyer's side and as a consequence to a low willingness to pay and a lower propensity to buy at all (Kim and Ahn 2007). In this case, one customer group might be willing to subsidize the other customer group's low willingness to pay. For example, on e-marketplaces, the buyer's fee can be (partly) subsidized by the seller's fee (Lin et al. 2011). Also with regard to escrow services, which secure the transfer of payments between buyer and seller on e-marketplaces, the seller usually has a higher incentive than the buyer to pay the escrow service provider (Hu et al. 2004): The escrow service rewards him with more online transactions and higher revenues since the service increases the buyers' trust as well as their willingness to pay.

Proposition 1.5: When customers' willingness to pay is low due to information asymmetry, choose a mix of revenue mechanisms that subsidizes the group of customers with a low willingness to pay and combine them with trust-enhancing measures.

There are cases, where some customers are willing to pay for the product or service, but other customer groups are not. This is true for the digital music industry: Offerings exist on a subscription basis, e.g. Napster 2.0 gives access to an online library of titles for a membership fee (Papies et al. 2011), or on a purchase basis, e.g. on iTunes each song can be bought for a micropayment (Bustinza et al. 2013), but they exclude those customers that have a near-zero willingness to pay. Offering a free version of the product maximizes market size by attracting new customers, who previously did not engage in commercial downloading (Papies et al. 2011). These customers can indirectly lead to revenues through advertising.

Proposition 1.6: When there are differences in customers' willingness to pay, combine revenue mechanisms that charge the customer directly and indirectly (e.g. subscription and advertising; freemium). 
However, when one version is for free or a competitor offers a free alternative, customers are increasingly reluctant to pay (Casero-Ripollés and Izquierdo-Castillo 2013). Therefore, the paid alternative has to be clearly differentiated form the free one in order to prohibit cannibalization effects. This differentiation can come from the product or service itself, such as highly specialized news (Kerrigan and Graham 2010), from the providers image (Benghozi and Lyubareva 2014), or from incentives provided to the customer. The latter case is presented by Feng (2009), where the customer gets a commission when he resells the digital content to other customers.

Proposition 1.7: Only when alternative versions of a product or service are clearly differentiated, offer a paid alternative while the other one is free of charge.

If this differentiation capability is not given and there are free offerings in the market - either provided by the own business or by a competitor - offering a paid version is not viable as this alternative is cannibalized by the free alternative (Deodhar et al. 2012). In this case, the business is usually financed by a third party (Clemons and Madhani 2011).

Proposition 1.8: When there is a free offering of the product or service in the market and the business cannot provide a differentiated version, choose indirect revenue mechanisms (e.g. advertising).

\subsection{The Indirect Influence of the Type of Offering on Revenue Mechanisms}

Depending on the type of offering (i.e. brokerage, experience, software, content), some of the above mentioned constraints are more relevant than others. Hence, as the type of offering has an influence on the constraints, it also indirectly influences the managerial decision on viable revenue mechanisms.

Experience goods are likely to differentiate themselves with a highly specialized offer as they often give access to a specific virtual world (Hinz and Spann 2008) or community (Oestreicher-Singer and Zalmanson 2013). This often goes hand in hand with a lock-in effect (Wu and Banker 2010; Roquilly 2011): Customers invest time and effort in building up their social networks, communities, or avatars which increases their switching costs. The differentiated offering as well as the lock-in effect leads to a higher willingness to pay of the customer. Therefore (cf. propositions 1.2 and 1.3),

Proposition 2.1: For experience products / services, leverage differentiation capabilities, the lock-in effect, and the resulting higher willingness to pay by choosing revenue mechanisms that charge the customer directly (e.g. subscription).

For content goods and services, it is often not that easy to differentiate themselves from competing offerings and to create a lock-in effect. Due to free offerings in the market, customers are becoming unaccustomed to pay for content (Kerrigan and Graham 2010), leading to an extremely low willingness to pay. In this situation the consumer cannot be charged directly. However, this might change, if the content goods and services manage to differentiate themselves after all, e.g. through the 
business's reputation, experience, and special content (Benghozi and Lyubareva 2014) or by allowing customers to resell the purchased content (Feng et al. 2009). Hence (cf. propositions 1.4, 1.7, 1.8),

Proposition 2.2: For content products / services, leverage differentiation capabilities by choosing revenue mechanisms that charge the customer directly (e.g. subscription); if the offering cannot differentiate itself, choose revenue mechanisms that charge the customer indirectly (e.g. advertising).

Regarding software and computing products / services, the willingness to pay differs among different customer groups and is often unknown (Bhargava and Sundaresan 2004; Das et al. 2011). In order to adapt to different or unknown customers' willingness to pay, a frequent strategy is to offer various versions of a product or service with differing quality levels. Chen and Seshadri (2007) define quality in this context as a multidimensional construct whereas these dimensions can be, for instance, convenience, features, support, or novelty. By versioning the seller can serve multiple customer groups with different willingness to pay and thereby maximize revenues (e.g. different versions of operating systems for either business or private users). A lock-in effect is often hard to implement, as customers are reluctant to be in long-term contracts (Desai and Currie 2005) and are often only willing to pay for the services they actually use (Khanagha et al. 2014). However, a lock-in effect can be established when the customer gets confidence in the business itself, e.g. because of its longevity (Currie et al. 2007). Thus (cf. propositions 1.3, 1.6, 1.7),

Proposition 2.3: For software and computing products / services, account for the differences in customers' willingness to pay by providing different versions of your offering with a combination of direct (e.g. pay-per-use) and indirect (e.g. advertising) revenue mechanisms while ensuring a clear differentiation of the different versions.

In the case of brokerage services, the problem of information asymmetry can be relevant. This can be mitigated by trust enhancing measures (e.g. escrow services) or subsidization where the customer group with the higher willingness to pay subsidizes the one with the lower willingness to pay (Lin et al. 2011; Hu et al. 2004). Using subsidization effects is also appropriate in the absence of information asymmetry when one customer group is simply not willing to pay for the service like in the case of search engines (Clemons and Madhani 2011). Hence (cf. propositions 1.4, 1.5, 1.6),

Proposition 2.4: For brokerage services, mitigate information asymmetry or account for differences in customers' willingness to pay by choosing a mix of revenue mechanisms that subsidizes the group of customers with a low willingness to pay and - if necessary - by combining them with trust-enhancing measures. 


\subsection{The Indirect Influence of the Business' Stage of Evolution on Revenue Mechanisms}

Like the type of digital offering, the business's stage of evolution influences the constraints and therefore indirectly influences the choice of revenue mechanisms.

Independent of the type of digital offering, all digital products and services are information goods and thus have special characteristics: First, the costs for the initial development are relatively high, but the cost for reproduction and distribution are only marginal; second, degradation, meaning the reduction of the product's or service's quality, is accomplished easily (Y.-J. Chen and Seshadri 2007; Brousseau and Penard 2007). In an early stage of the digital business - this can be a business that was just transferred from an offline to an online version, as in the case of music or news media (Benghozi and Lyubareva 2014; Papies et al. 2011), or it can be a business that was purely invented for the digital world, e.g. Internet search engines (Clemons and Madhani 2011) - the focus has to be on attracting a large customer base to spread the initial development costs (Y.-J. Chen and Seshadri 2007).

As mentioned above, in an early stage the customer's willingness to pay is often low. Hence, in the beginning, businesses offer their products and services often for free, so that the revenue potential lies not in the customer base itself but in a third party. A typical revenue mechanism in this stage is advertising ( $\mathrm{Wu}$ and Banker 2010). Since the user is not the paying party, the business model is attractive for him: Software products are distributed to a large customer base (Deodhar et al. 2012), information websites attract traffic (Wu and Banker 2010), and gaming companies build up an online community (Roquilly 2011). With regard to the fact that advertising reduces the attractiveness of a website or system, it may also be even advisable to have less advertising at the beginning to attract more customers and to overinvest in content (Dewan et al. 2003). Another revenue mechanism suitable in the beginning is freemium. A provider adopting a freemium revenue mechanism offers its basic services for free and grants additional premium services for paying customers (OestreicherSinger and Zalmanson 2013; Brousseau and Penard 2007). The idea is that the free services attract a large customer base while a small proportion opts for the premium services and thus generates revenues for the provider (Casero-Ripollés and Izquierdo-Castillo 2013). Customers consuming the free services can also be seen as potential future revenues as there usually is a certain conversion rate from free service users to paying users (Deodhar et al. 2012).

A nice example is a content website, which provides both online radio and social networking services (Oestreicher-Singer and Zalmanson 2013). While the basic use is free, more sophisticated users are charged a monthly fee for premium services (e.g. increased bandwidth). Another example can be found in the online gaming industry. In free-to-play online games the user can play free of charge but has, for example, to pay for access to certain virtual items (Roquilly 2011). 
Proposition 3.1: In an early stage of digital businesses, chose revenue mechanisms that allow the customer to get the (basic) product or service for free (e.g. advertising, freemium).

As not all offerings can be combined with an advertising or freemium revenue mechanism, the enlargement of the customer base can also be fostered by choosing revenue mechanisms which charge the customer directly but where the service provider absorbs the risk of the offering. Examples are computing services with a pay-per-use revenue mechanism: The customers are charged directly but only pay for the amount they actually use (Concha et al. 2010). In this case, the service provider absorbs all the risk of maintaining the whole infrastructure with no planning reliability so that the customer can try out the service risk free (Bhargava and Sundaresan 2004).

Proposition 3.2: In an early stage of digital businesses, chose revenue mechanisms that allow your customer to try out your offering risk free (e.g. pay-per-use).

When the business evolves from an early to a more mature stage, the business not only persists for a longer period of time in the digital world, but has also managed to attract a sufficient number of customers. However, a large number of customers alone does not ensure a high value capture. Only when the customer base can be leveraged by capturing an adequate revenue share per customer, the business is viable over time. Therefore, after building up a customer base in the emerging phase, the business has to retain its customer base in the mature phase while at the same time focusing on revenue maximization to stay viable.

One way of maximizing revenue is leveraging an established lock-in effect. The existence of these lock-in effects is higher in the mature phase, as customers invested in the product or service, got used to it, or simply were convinced of its value. After this lock-in effect is established, websites that overinvested in content to attract more customers can now increase their advertising rate to leverage the customer base and render the business more profitable. Businesses with a freemium revenue mechanism are likely to have a higher free to fee conversion rate, meaning that more customers switch from the free service to the one they have to pay for and thereby increasing the overall revenue. Since more customers are willing to pay for the digital product at this stage, also other revenue mechanisms where the customer is charged directly, for example subscription, are now adequate (Wu and Banker 2010; Clemons 2009).

Proposition 3.3: In a mature stage of your businesses, leverage the lock-in effect by choosing an advertising revenue mechanism with an increased advertising rate, by choosing a freemium revenue mechanism with a larger paying customer base, or by choosing revenue mechanisms that charge customers directly (e.g. subscription, pay-per-use).

Also with regard to offerings that already charged the customer directly in the early stage of the business but with the service provider absorbing all the risk, a lock-in effect offers the possibility to 
get an advanced commitment for a minimum purchase quantity, where the users - at least partially bear the risk of infrastructure provided (Bhargava and Sundaresan 2004).

Proposition 3.4: In the mature stage of your businesses, leverage the lock-in effect by choosing revenue mechanisms that allow you to transfer the risk (partially) to your customer (e.g. pay-per-use with an advanced commitment for a minimum purchase quantity).

Regarding advertising supported businesses, information asymmetry can exist between the service provider and the advertiser when advertisers have to pay on a performance-based model, i.e. they are charged when potential customers click on their ads (Lin et al. 2012). Liu et al. (2010) examine a case where advertisers bid their willingness to pay per click on their advertising, whereas the advertising provider defines different minimum bids according to the advertiser's expected click generating potential (i.e. the advertising provider asks for a lower minimum bid per click when the advertiser has a high click generating potential). However, in an early phase, the service provider has no knowledge on the advertiser's click generating potential, which leads to the problem of information asymmetry. In this case a performance-based revenue mechanism is not suitable. In a mature stage, the service provider has accumulated information on the advertisers click through rates and has therefore information on the advertiser's outcome generating potential. Service providers will then opt for a performance-based revenue mechanism that maximizes their own revenues in order to leverage their advertiser base which was build up in the early stage (Liu et al. 2010).

Proposition 3.5: In a mature stage of your advertising supported business, leverage the mitigated information asymmetry by choosing revenue mechanisms that allow you to benefit from the accumulated information on advertiser's performance (e.g. pay-per-use where usage is measured based on clicks and the clicks are priced with regard to the advertiser's click generating potential).

\section{Discussion and Implications}

The viability theory for digital businesses enriches extant research in multiple ways. In this paper, the general viability theory of Aubin et al. (2011) is introduced as a basic rational to a new field: Whereas researchers have applied this general theory rather to biological, mathematical, or engineering areas (De Lara et al. 2014; Krawczyk and Pharo 2013; Panagou and Kyriakopoulos 2013), we transfer its core logic to digital businesses. Thereby, our research is located at the frontier of IS and business and supports Aubin et al.'s statement that the general viability theory is applicable to all evolutionary systems as they all have to adapt to their context to stay viable. Our analysis suggests a more detailed view on the context by splitting it up into different contextual categories - type of digital offering, stage of evolution, constraints - that are of interest regarding the evolution of revenue mechanisms. This is not only an enrichment regarding Aubin et al.'s viability theory but also an extension to existing research on business models: Papers that touch the topic of business model adaption often 
remain on the surface by stating that the business model and all its components have to be aligned with changing environmental conditions (Hedman and Kalling 2003; Morris et al. 2005). Hence, we aimed at complying with other researchers' request to include the dynamic aspect into the business model design as business model evolution is highly path-dependent (McGrath 2010). For example, if it is a viable decision to implement a subscription revenue mechanism depends on the fact if the same service has been offered for free in the past.

The combination of viability theory and business model design seems fitting as evolution in the context of business is not understood in a biological sense but rather as a consequence of decisions taken within the organization (Spieth et al. 2014). Thus, a business's evolution - and its viability - is triggered by conscious design choices (Mettler and Eurich 2012). Regarding these design choices, our study focuses on revenue mechanisms. This restriction aside, our research addresses all kinds of digital businesses with various offerings, on different maturity levels, operating in diverse competitive landscapes, and that serve customers with varying willingness to pay. By aggregating and analyzing extant research that rather focuses on specific cases or industries when analyzing revenue mechanisms (Krueger and Swatman 2004; Roquilly 2011; Papies et al. 2011), we can aim for a higher level of generalizability.

In addition to the enrichment of extant research, our paper has also practical implications. As each proposition of our viability theory describes a situation and gives a corresponding recommendation regarding which revenue mechanism to use, it acts as guidance for managers. Since the propositions are derived from a rigorous literature review, they include aspects that have been relevant for the discussed cases in the literature base. Thereby, the effectiveness as well as the efficiency of decisions are increased. The former is enhanced as the propositions are derived on the basis of real life cases and thereby ensure that the respective revenue mechanism proofed to be suitable in a similar situation. The latter is improved because managers can use the propositions as guiding principles and can build upon the experience of other businesses when thinking about possible revenue mechanisms for their offerings. This increase in efficiency is further leveraged when managers use the propositions to formulate a roadmap for the design of their revenue mechanisms. For example, they could decide on revenue mechanisms in an early stage of the business and already plan for revenue mechanisms for the mature stage. They could also plan for alternative future scenarios and already select possible revenue mechanisms for each situation. In this sense, the propositions on the one hand help to imagine relevant changes in the business's environment; on the other hand, they act as management principles that are appropriate to the evolving context (Sanchez and Heene 1997).

Usually, the propositions should support managers in choosing a revenue mechanism in a given situation, in which they have only limited control over the contextual factors. However, sometimes the propositions can help vice versa: In case a manager has a specific revenue mechanism in mind that he would like to implement, the propositions reveal under which circumstances such a revenue 
mechanism is suitable. The manager can then try to establish this situation and implement the intended revenue mechanism. For example, in case the manager would like to opt for a subscription revenue mechanism but has a music service that is very similar to competing services that are offered for free, the propositions would indicate that he would have to either differentiate his service from competing services or manage to establish a lock-in effect resulting in a higher willingness to pay. On the basis of the propositions he could then decide - like in the case presented by Oestreicher-Singer (2013) - to extend his content service to an experience product / service by offering a community feature where users would spend time in discussing different music styles, preparing playlists, etc. and thereby create a lock-in effect.

\section{Conclusion}

In summary, our paper enhances the research of digital businesses as well as provides managers with guidelines that should reduce their decision uncertainty when designing revenue mechanisms. In order to do so, we performed a grounded theory literature review to identify categories that are relevant for a digital business's viability - type of digital offering, stage of evolution, constraints, revenue mechanisms, and viability - as well as their respective properties. On that basis, we derived a viability theory for digital businesses consisting of 17 propositions to support managerial decisions. Since managers can plan for potential scenarios, they can react quickly to the fast changing market environment. Hence, the propositions help managers in increasing the effectiveness and efficiency of their decisions on revenue mechanisms and aim at fostering the viability of their business over time.

Despite our efforts to achieve the highest levels of objectivity, accuracy, and validity, our analysis is not without limitations. The different cases that were discovered in our literature review often do not provide their evidence in a time-series manner, but rather describe the revenue mechanisms in a specific context. However, our examination of accumulated knowledge described in the identified cases present some vital considerations for managers and researchers alike that are interested in an evolutionary perspective on digital business model design.

We hope that future research will further guide managerial decisions on digital business model design. From our perspective, there are several opportunities for research in relation to business model evolution in the digital context: Since we focused our study specifically on revenue mechanisms, further studies may examine evolution of other business model components (e.g. value proposition or customer base). In addition, there is also a need for more practical case descriptions on how companies successfully developed their digital business models over time and - more importantly - also case studies that report on transitions which did not lead to viable digital businesses. Additional cases could then help to test and verify our propositions as well as to formulate new ones. On the basis of the accumulated knowledge, design patterns could be developed that would connect viable business model decisions to a given context. Analogously to design patterns in architecture (Alexander et al. 1977) or 
software engineering (Gamma et al. 1995), these design patterns would provide reusable knowledge that could guide managerial decisions regarding the design of digital business models. Thereby, these business model design patterns could provide managers with an overview regarding existing business logics that proved to be suitable in a similar context. As the business's context changes over time, the design patterns could be used in an iterative way to adapt the business model accordingly. Here, the design patterns would act as a means to business model evolution to ensure the business's viability over time. Moreover, the design patterns could be developed for different industries to account for industry specific requirements and problems.

\section{References}

Alexander, C., Ishikawa, S., Silverstein, M., Jacobson, M., Fiksdahl-King, I., \& Angel, S. (1977). A Pattern Language. New York: Oxford University Press.

Amberg, M., \& Schröder, M. (2007). E-business models and consumer expectations for digital audio distribution. Journal Of Enterprise Information Management, 20(3), 291-303.

Amit, R., \& Zott, C. (2001). Value creation in e-business. Strategic Management Journal, 22, 493520.

Amit, R., \& Zott, C. (2012). Creating value through business model innovation. MIT Sloan Management Review, 53(3), 41-49.

Aubin, J.-P., Bayen, A. M., \& Saint-Pierre, P. (2011). Viability Theory: New Directions. Heidelberg: Springer.

Bapna, R., Goes, P., \& Gupta, A. (2009). Auctioning vertically integrated online sevices: Computational approaches for real-time allocation. Journal of Management Information Systems, 25(3), 65-97.

Benghozi, P.-J., \& Lyubareva, I. (2014). When organizations in the cultural industries seek new business models: A case study of the French online press. International Journal of Arts Management, 16(3), 6-19.

Berman, S. J., Kesterson-Townes, L., Marshall, A., \& Srivathsa, R. (2012). How cloud computing enables process and business model innovation. Strategy \& Leadership, 40(4), 27-35.

Bharadwaj, A., El Sawy, O. A., Pavlou, P. A., \& Venkatraman, N. (2013). Digital business strategy: Toward a next generation of insights. MIS Quarterly, 37(2), 471-482.

Bhargava, H. K., \& Sundaresan, S. (2004). Computing as utility: Managing availability, commitment, and pricing through contingent bid auctions. Journal of Management Information Systems, 21(2), 201-227.

Bourreau, M., Gensollen, M., \& Moreau, F. (2012). The impact of a radical innovation on business models: Incremental adjustments or big bang? Industry and Innovation, 19(5), 415-435.

Brousseau, E., \& Penard, T. (2007). The economics of digital business models: A framework for analyzing the economics of platforms. Review of Network Economics, 6(2), 81-114. 
Bustinza, O. F., Vendrell-Herrero, F., Parry, G., \& Myrthianos, V. (2013). Music business models and piracy. Industrial Management Data Systems, 113(1), 4-22.

Casadesus-Masanell, R., \& Hervas-Drane, A. (2010). Competing against online sharing. Management Decision, 48(8), 1247-1260.

Casadesus-Masanell, R., \& Zhu, F. (2013). Business model innovation and competitive imitation: The case of sponsor-based business models. Strategic Management Journal, 34(4), 464-482.

Casero-Ripollés, A., \& Izquierdo-Castillo, J. (2013). Between decline and a new online business model: The case of the Spanish newspaper industry. Journal of Media Business Studies, 10(1), 63 78.

Chen, L.-d., Gillenson, M. L., \& Sherrell, D. L. (2002). Enticing online consumers: An extended technology acceptance perspective. Information \& Management, 39(8), 705-719.

Chen, Y.-J., \& Seshadri, S. (2007). Product development and pricing strategy for information goods under heterogeneous outside opportunities. Information Systems Research, 18(2), 150-172.

Chesbrough, H. (2007). Business model innovation: It's not just about technology anymore. Strategy \& Leadership, 35(6), 12-17.

Chesbrough, H. (2010). Business model innovation: Opportunities and barriers. Long Range Planning, 43(2), 354-363.

Clemons, E. K. (2009). Business models for monetizing internet applications and web sites: Experience, theory, and predictions. Journal of Mangement Information Systems, 26(2), 15-41.

Clemons, E. K., \& Madhani, N. (2011). Regulation of digital businesses with natural monopolies or third-party payment business models: Antitrust lessons from the analysis of Google. Journal of Management Information Systems, 27(3), 43-80.

Concha, D., Espadas, J., Romero, D., \& Molina, A. (2010). The e-HUB evolution: From a custom software architecture to a software-as-a-service implementation. Computers In Industry, 61(2), 145-151.

Corbin, J. M., \& Strauss, A. (1990). Grounded theory research: Procedures, canons, and evaluative criteria. Qualitative sociology, 13(1), 3-21.

Currie, W. L. (2004). Value creation from the application service provider e-business model: The experience of four firms. The Journal of Enterprise Information Management, 17(2), 117-130.

Currie, W. L., Joyce, P., \& Winch, G. (2007). Evaluating application service provisioning using system dynamics methodology. British Journal of Management, 18(2), 172-191.

Das, S., Du, A. Y., Gopal, R., \& Ramesh, R. (2011). Risk management and optimal pricing in online storage grids. Information Systems Research, 22(4), 756-773.

De Lara, M., Martinet, V., \& Doyen, L. (2014). Satisficing versus optimality: Criteria for sustainability. Bulletin of Mathematical Biology, 77(2), 281-297.

Del Giudice, M., \& Straub, D. (2011). IT and entrepreneurism: An on-again, off-again love affair or a marriage? MIS Quarterly, 35(4), iii-viii. 
Demil, B., \& Lecocq, X. (2010). Business model evolution: In search of dynamic consistency. Long Range Planning, 43(2), 227-246.

Deodhar, S. J., Saxena, K. B. C., Gupta, R. K., \& Ruohonen, M. (2012). Strategies for software-based hybrid buiness models. Journal of Strategic Information Systems, 21, 274-294.

Desai, B., \& Currie, W. (2005). Towards the ASP e-business model: A conceptual framework for mapping ASP specific value propositions. Journal of Internet Commerce, 4(1), 79-101.

Dewan, R. M., Freimer, M. L., \& Zhang, J. (2003). Management and valuation of advertisementsupported web sites. Journal of Management Information Systems, 19(3), 87-98.

Dosi, G., \& Nelson, R. R. (1994). An introduction to evolutionary theories in economics. Journal of Evolutionary Economics, 4, 153-172.

Eurich, M., Giessmann, A., Mettler, T., \& Stanoevska-Slabeva, K. (2011). Revenue streams of cloudbased platforms: Current state and future directions. Proc. of the $17^{\text {th }}$ Americas Conference on Information Systems, Detroit, MI.

Fagerberg, J. (2003). Schumpeter and the revival of evolutionary economics: An appraisal of the literature. Journal of Evolutionary Economics, 13(2), 125-159.

Feng, Y., Guo, Z., \& Chiang, W.-Y. K. (2009). Optimal digital content distribution strategy in the presence of the consumer-to-consumer channel. Journal of Management Information Systems, 25(4), 241-270.

Ford, C. M., \& Gioia, D. A. (2000). Factors influencing creativity in the domain of managerial decision making. Journal of Management, 26(4), 705-732.

Gamma, E., Helm, R., Johnson, R., \& Vlissides, J. (1995). Design Patterns: Elements of Reusable Object-Oriented Software. Reading: Addison-Wesley.

Glaser, B. G., \& Strauss, A. L. (1967). The Discovery of Grounded Theory: Strategies for Qualitative Research. Chicago, IL: Aldine Publishing.

Golinelli, G. M., Pastore, A., Gatti, M., Massaroni, E., \& Vagnani, G. (2011). The firm as a viable system: Managing inter-organisational relationships. Sinergie Italian Journal of Management, 58(2), 65-98.

Günzel, F., \& Holm, A. B. (2013). One size does not fit all - Understanding the front-end and backend of business model innovation. International Journal of Innovation Management, 17(1), 13400021-134000234.

Hedman, J., \& Kalling, T. (2003). The business model concept: theoretical underpinnings and empirical illustrations. European Journal of Information Systems, 12(1), 49-59.

Hinz, O., Hann, I.-H., \& Spann, M. (2011). Price discrimination in e-commerce? An examination of dynamic pricing in name-your-own price markets. MIS Quarterly, 35(1), 81-98.

Hinz, O., \& Spann, M. (2008). The impact of information diffusion on bidding behavior in secret reserve price auctions. Information Systems Research, 19(3), 351-368. 
Hu, X., Lin, Z., Whinston, A. B., \& Zhang, H. (2004). Hope or hype: On the viability of escrow services as trusted third parties in online auction environments. Information Systems Research, 15(3), 236-249.

Johnson, M., Christensen, C., \& Kagermann, H. (2008). Reinventing your business model. Harvard Business Review, 86(12), 51-59.

Kerrigan, F., \& Graham, G. (2010). Interaction of regional news-media production and consumption through the social space. Journal of Marketing Management, 26(3-4), 302-320.

Khanagha, S., Volberda, H., \& Oshri, I. (2014). Business model renewal and ambidexterity: Structural alteration and strategy formation process during transition to a Cloud business model. $R \& D$ Management, 44(3), 322-340.

Kim, M.-S., \& Ahn, J.-H. (2007). Management of trust in the e-marketplace: The role of the buyer's experience in building trust. Journal of Information Technology, 22, 119-132.

Kishore, R., \& McLean, E.R. (2002). The next generation enterprise: A CIO perspective on the vision, its impacts, and implementation challenges. Information Systems Frontiers, 4(1), 121-138.

Koo, C., Song, J., Kim, Y. J., \& Nam, K. (2007). Do e-business strategies matter? The antecedents and relationship with firm performance. Information Systems Frontiers, 9(2-3), 283-296.

Krawczyk, J. B., \& Pharo, A. (2013). Viability theory: An applied mathematics tool for achieving dynamic systems' sustainability. Mathematica Applicanda, 41(1), 97-126.

Krishnan, R., Smith, M. D., Tang, Z., \& Telang, R. (2007). Digital business models for peer-to-peer networks: Analysis and economic issue. Review of Network Economics, 6(2), 194-213.

Krueger, C. C., \& Swatman, P. M. C. (2004). Developing e-business models in practice: The case of the regional online newspaper. International Journal of Information Technology and Management, $3(2-4), 157-172$.

Laffey, D. (2010). Comparison websites: Evidence from the service sector. The Service Industries Journal, 30(12), 1939-1954.

Lehmann, H. (2001). Using grounded theory with technology cases: Distilling critical theory from a multinational information systems development project. Journal of Global Information Technology Management, 4(1), 45-60.

Li, S., Da Xu, L., \& Zhao, S. (2015). The Internet of Things: A survey. Information Systems Frontiers, 17(2), 243-259.

Lin, M., Ke, X., \& Whinston, A. B. (2012). Vertical differentiation and a comparison of online advertising models. Journal of Management Information Systems, 29(1), 195-235.

Lin, M., Li, S., \& Whinston, A. B. (2011). Innovation and price competition in a two-sided market. Journal of Management Information Systems, 28(2), 171-202.

Liu, D., Chen, J., \& Whinston, A. B. (2010). Ex ante information and the design of keyword auctions. Information Systems Research, 21(1), 133-153. 
March, J. G. (1994). Primer on Decision Making: How Decisions Happen. New York, NY: Simon and Schuster.

Marshall, M. N. (1996). Sampling for qualitative research. Family Practice, 13(6), 522-525.

McGrath, R. G. (2010). Business models: A discovery driven approach. Long Range Planning, 43(2), 247-261.

Mettler, T., \& Eurich, M. (2012). A design pattern-based approach for analyzing e-health business models. Health Policy and Technology, 1(2), 77-85.

Mitchell, J. R., Shepherd, D. A., \& Sharfman, M. P. (2011). Erratic strategic decisions: When and why managers are inconsistent in strategic decision making. Strategic Management Journal, 32(7), 683-704.

Morris, M., Schindehutte, M., \& Allen, J. (2005). The entrepreneur's business model: Toward a unified perspective. Journal of Business Research, 58(6), 726-735.

Nelson, R. R., \& Winter, S. G. (1982). An Evolutionary Theory of Economic Change. Cambridge, MA: Belknap Press.

Oestreicher-Singer, G., \& Zalmanson, L. (2013). Content or community? A digital business strategy for content providers in the social age. MIS Quarterly, 37(2), 591-616.

Okoli, C. (2012). A critical realist guide to developing theory with systematic literature reviews. http://ssrn.com/abstract=2115818. Accessed 07.08.2015.

Osterwalder, A. (2004). The Business Model Ontology: A Proposition in a Design Science Approach. University of Lausanne,

Osterwalder, A., \& Pigneur, Y. (2010). Business Model Generation. Hoboken, NJ: John Wiley \& Sons.

Osterwalder, A., Pigneur, Y., Bernarda, G., \& Smith, A. (2015). Value Proposition Design: How to Create Products and Services Customers Want. Hoboken, NJ: John Wiley \& Sons.

Osterwalder, A., Pigneur, Y., \& Tucci, C. L. (2005). Clarifying business models: Origins, present, and future of the concept. Communications Of The AIS, 16(1), 1-25.

Panagou, D., \& Kyriakopoulos, K. J. (2013). Viability control for a class of underactuated systems. Automatica, 49(1), 17-29.

Papadakis, V. M., Lioukas, S., \& Chambers, D. (1998). Strategic decision-making processes: The role of management and context. Strategic Management Journal, 19(2), 115-147.

Papies, D., Eggers, F., \& Wlömert, N. (2011). Music for free? How free ad-funded downloads affect consumer choice. Journal Of The Academy Of Marketing Science, 39(5), 777-794.

Porra, J. (2000). Electronic commerce Internet strategies and business models - A survey. Information Systems Frontiers, 1(4), 389-399.

Roquilly, C. (2011). Control over virtual worlds by game companies: Issues and recommendations. MIS Quarterly, 35(3), 653-671. 
Rowe, F. (2014). What literature review is not: Diversity, boundaries and recommendations. European Journal of Information Systems, 23(3), 241-255.

Sanchez, R., \& Heene, A. (1997). Managing for an uncertain future: A systems view of strategic organizational change. International Studies of Management \& Organization, 27(2), 21-42.

Schwaninger, M. (2006). Theories of viability: A comparison. Systems Research and Behavioral Science, 23(3), 337-347.

Shaw, M. J. (1999). Electronic commerce: Review of critical research issues. Information Systems Frontiers, 1(1), 95-106.

Shaw, M. J. (2000a). Electronic commerce: Integration of web technologies with business models. Information Systems Frontiers, 1(4), 327-328.

Shaw, M. J. (2000b). From e-business to electronic commerce: Integration of web technologies with business models. Information Systems Frontiers, 2(1), 5-6.

Solaimani, S., Bouwman, H., \& Itälä, T. (2015). Networked enterprise business model alignment: A case study on smart living. Information Systems Frontiers, 17(4), 871-887.

Spieth, P., Schneckenberg, D., \& Ricart, J. E. (2014). Business model innovation - State of the art and future challenges for the field. $R \& D$ Management, 44(3), 237-247.

Teece, D. J. (2010). Business models, business strategy and innovation. Long Range Planning, 43(2), 172-194.

Timmers, P. (1998). Business models for electronic markets. Electronic Markets, 8(2), 3-8.

Urquhart, C., Lehmann, H., \& Myers, M. D. (2010). Putting the 'theory' back into grounded theory: Guidelines for grounded theory studies in information systems. Information Systems Journal, 20(4), 357-381.

Vecchiato, R. (2012). Environmental uncertainty, foresight and strategic decision making: An integrated study. Technological Forecasting and Social Change, 79(3), 436-447.

Webster, J., \& Watson, R. T. (2002). Analyzing the past to prepare for the future: Writing a literature review. MIS Quarterly, 26(2), 13-23.

Williams, K., Chatterjee, S., \& Rossi, M. (2008). Design of emerging digital services: A taxonomy. European Journal of Information Systems, 17, 505-517.

Williamson, P. J. (2010). Cost innovation: Preparing for a 'value-for-money' revolution. Long Range Planning, 43(2), 343-353.

Winter, S. G., \& Szulanski, G. (2001). Replication as strategy. Organization Science, 12(6), 730-743.

Wolfswinkel, J. F., Furtmueller, E., \& Wilderom, C. P. M. (2013). Using grounded theory as a method for rigorously reviewing literature. European Journal of Information Systems, 22(1), 45-55.

Wu, S.-y., \& Banker, R. D. (2010). Best pricing strategy for information services. Journal Of The Association for Information Systems, 11(6), 339-366.

Zott, C., Amit, R., \& Massa, L. (2011). The business model: Recent developments and future research. Journal of Management, 37(4), 1019-1042. 


\section{Appendix: Overview of Cases}

\begin{tabular}{|c|c|c|c|c|c|}
\hline Case/reference & Revenue mechanisms & $\begin{array}{l}\text { Type of digital } \\
\text { offering }\end{array}$ & $\begin{array}{l}\text { Stage of } \\
\text { evolution }\end{array}$ & Constraints & Viability \\
\hline $\begin{array}{l}\text { (Amberg and } \\
\text { Schröder 2007) }\end{array}$ & $\begin{array}{l}\text { Pay-per-use: Based on "pay-per-download" } \\
\text { (dependent or independent of the supplier's } \\
\text { technology). } \\
\text { Subscription: Based on a flat rate (for copying } \\
\text { audio content in order to transfer it to another } \\
\text { device, an additional fee is required). Additional } \\
\text { services, e.g. playlists, are provided to attract } \\
\text { customers for a contract that lasts at least } 30 \\
\text { days. } \\
\text { Purchase: Indirect sales through customers } \\
\text { reselling the digital audio content (for a low- } \\
\text { rated commission). }\end{array}$ & $\begin{array}{l}\text { Content products / } \\
\text { services: Music. }\end{array}$ & \begin{tabular}{l|l|}
- & \\
\end{tabular} & $\begin{array}{l}\text { Willingness to pay; free offerings in } \\
\text { the market: Consumers share music } \\
\text { illegally. }\end{array}$ & - \\
\hline $\begin{array}{l}\text { (Amit and Zott } \\
2012)\end{array}$ & $\begin{array}{l}\text { Subscription } \\
\text { Purchase (piecemeal pricing, value-based } \\
\text { pricing for time sensitive content). }\end{array}$ & $\begin{array}{l}\text { Content products / } \\
\text { services: Music and } \\
\text { news media. }\end{array}$ & - & Lock-in, differentiation capabilities & $\begin{array}{l}\text { Viability enhancing: Novelty, lock-in, } \\
\text { complementarities, and efficiency allow } \\
\text { charging the customer directly. }\end{array}$ \\
\hline $\begin{array}{l}\text { (Bapna et al. } \\
\text { 2009) }\end{array}$ & $\begin{array}{l}\text { Purchase: Second price auction (highest bidder } \\
\text { wins but pays the price of the next highest } \\
\text { bidder) for the case of a capacity-constrained } \\
\text { online service provider that offers various } \\
\text { classes of unique, one-time services that differ } \\
\text { in quality. }\end{array}$ & $\begin{array}{l}\text { Content products / } \\
\text { services: Webcasting of } \\
\text { live events, peer to peer } \\
\text { file sharing, video on } \\
\text { demand content. } \\
\text { Computing products } \\
\text { and services: Grid } \\
\text { computing resources. }\end{array}$ & - & $\begin{array}{l}\text { Willingness to pay is not known in } \\
\text { advance: Existence of several similar } \\
\text { services with different quality levels, } \\
\text { but consumers are only interested in } \\
\text { consuming one of them. }\end{array}$ & $\begin{array}{l}\text { Viability enhancing: Second price } \\
\text { auctions are revenue maximizing. }\end{array}$ \\
\hline $\begin{array}{l}\text { (Benghozi and } \\
\text { Lyubareva 2014) }\end{array}$ & $\begin{array}{l}\text { Purchase: Articles are sold per unit. } \\
\text { Additionally, articles in special formats (pdf), } \\
\text { special product bundles (e.g. newspaper with } \\
\text { free weekend magazines), and access to digital } \\
\text { archives can be sold. } \\
\text { Subscription } \\
\text { Advertising } \\
\text { Freemium: Only part of the site's offering is } \\
\text { offered for free. The site's content might be } \\
\text { either of inferior quality (e.g. outdated } \\
\text { information) or limited in supply (e.g. excerpts). }\end{array}$ & $\begin{array}{l}\text { Content products / } \\
\text { services: French press } \\
\text { websites. }\end{array}$ & $\begin{array}{l}\text { Early and } \\
\text { mature } \\
\text { stage }\end{array}$ & $\begin{array}{l}\text { Free offerings in the market: Domino } \\
\text { effect: Progressive generalization of free } \\
\text { offerings by all players. } \\
\text { Differentiation capabilities: } \\
\text { Newspaper's reputation, experience and } \\
\text { content leading to successful paid digital } \\
\text { circulation. }\end{array}$ & $\begin{array}{l}\text { Viability enhancing: Lock-in through } \\
\text { newspaper's reputation, experience, and } \\
\text { content is revenue maximizing. }\end{array}$ \\
\hline
\end{tabular}




\begin{tabular}{|c|c|c|c|c|c|}
\hline Case/reference & Revenue mechanisms & $\begin{array}{l}\text { Type of digital } \\
\text { offering }\end{array}$ & \begin{tabular}{|l|}
$\begin{array}{l}\text { Stage of } \\
\text { evolution }\end{array}$ \\
\end{tabular} & Constraints & Viability \\
\hline $\begin{array}{l}\text { (Berman et al. } \\
\text { 2012) }\end{array}$ & Pay-per-use & $\begin{array}{l}\text { Software and } \\
\text { computing services: } \\
\text { Cloud services. } \\
\end{array}$ & - & - & - \\
\hline $\begin{array}{l}\text { (Bharadwaj et al. } \\
\text { 2013) }\end{array}$ & $\begin{array}{l}\text { Subscription and advertising: Information- } \\
\text { based business models. }\end{array}$ & \begin{tabular}{|l|} 
Content products / \\
services: Music and \\
news media. \\
Experience products / \\
services: Social \\
networks. \\
Brokerage services: \\
Search engine (Google). \\
\end{tabular} & $\begin{array}{l}\text { Early and } \\
\text { mature } \\
\text { stage }\end{array}$ & $\begin{array}{l}\text { Willingness to pay: Information-based } \\
\text { businesses need to rethink their source } \\
\text { of value (subscription vs. advertising). }\end{array}$ & $\begin{array}{l}\text { Viability enhancing: Balance between } \\
\text { subscription and advertising is given. }\end{array}$ \\
\hline $\begin{array}{l}\text { (Bhargava and } \\
\text { Sundaresan } \\
\text { 2004) }\end{array}$ & $\begin{array}{l}\text { Purchase: Contingent bid auctions } \\
3 \text { Cases: } \\
\text { Advance commitment (AC): No-shows pay the } \\
\text { full price } \\
\text { No commitment (NC): No-shows do not pay at } \\
\text { all } \\
\text { Partial commitment (PC): No-shows pay a part } \\
\text { of the price }\end{array}$ & Computing services & $\begin{array}{l}\text { Early and } \\
\text { mature } \\
\text { stage }\end{array}$ & $\begin{array}{l}\text { Willingness to pay is not known. } \\
\text { Customers are reluctant to commit in } \\
\text { advance when they are new to the } \\
\text { service. } \\
\text { Lock-in: Established when users } \\
\text { understand the value of the technology. }\end{array}$ & $\begin{array}{l}\text { Viability reducing: When the NC case } \\
\text { is adopted for a too long time, viability is } \\
\text { destroyed as the provider bears all the } \\
\text { risk. } \\
\text { Viability enhancing: The NC case is } \\
\text { only viable in the early phase of the } \\
\text { business model (attracting customers } \\
\text { with a "no risk commitment"); as the } \\
\text { business matures it has to adopt the PC } \\
\text { and finally the AC. Thereby, the } \\
\text { customer reveals information about his } \\
\text { valuation as well as his demand } \\
\text { realization probabilities. }\end{array}$ \\
\hline $\begin{array}{l}\text { (Bourreau et al. } \\
\text { 2012) }\end{array}$ & $\begin{array}{l}\text { Purchase: Directly through content sale or } \\
\text { indirectly through revenues generated from } \\
\text { other markets; e.g. mobile phone ringtones. } \\
\text { Subscription } \\
\text { Advertising: Often the main source of revenue. }\end{array}$ & $\begin{array}{l}\text { Content products / } \\
\text { services: Music. }\end{array}$ & $\begin{array}{l}\text { Early and } \\
\text { mature } \\
\text { stage }\end{array}$ & $\begin{array}{l}\text { Differentiation capabilities: } \\
\text { Distinction of product / service through } \\
\text { personal addressing (e.g. on the basis of } \\
\text { past consumption). }\end{array}$ & $\begin{array}{l}\text { Viability enhancing: Experimentation } \\
\text { with different revenue mechanisms to } \\
\text { find the most effective model. }\end{array}$ \\
\hline
\end{tabular}




\begin{tabular}{|c|c|c|c|c|c|}
\hline Case/reference & Revenue mechanisms & $\begin{array}{l}\text { Type of digital } \\
\text { offering }\end{array}$ & $\begin{array}{l}\text { Stage of } \\
\text { evolution }\end{array}$ & Constraints & Viability \\
\hline $\begin{array}{l}\text { (Brousseau and } \\
\text { Penard 2007) }\end{array}$ & $\begin{array}{l}\text { Purchase } \\
\text { Advertising } \\
\text { Freemium: Providing some functions free of } \\
\text { charge. }\end{array}$ & $\begin{array}{l}\text { Content products / } \\
\text { services } \\
\text { Brokerage services }\end{array}$ & \begin{tabular}{|l|} 
Early and \\
mature \\
stage
\end{tabular} & $\begin{array}{l}\text { Information asymmetry: User's } \\
\text { information can be requested or tracked. } \\
\text { On that basis a database with value for } \\
\text { different marketing practices can be } \\
\text { generated. } \\
\text { Differentiation capabilities: Through } \\
\text { bundling the provision of various } \\
\text { information goods. } \\
\text { Free offerings in the market: The } \\
\text { competition might restrain them from } \\
\text { capturing high revenues. }\end{array}$ & $\begin{array}{l}\text { Viability enhancing: In the early stage, } \\
\text { the service is provided for free. In a } \\
\text { distant future, however, revenue models } \\
\text { could converge: combining value-added } \\
\text { packages generating direct revenues and } \\
\text { standard quality packages generating } \\
\text { indirect revenues. } \\
\text { Participants that are less likely to pay for } \\
\text { intermediation services can be } \\
\text { subsidized, which increases their } \\
\text { participation and as a consequence } \\
\text { increases the platform's attractiveness } \\
\text { for other participants. Overall, the result } \\
\text { is a higher number of participants using } \\
\text { the platform. }\end{array}$ \\
\hline $\begin{array}{l}\text { (Bustinza et al. } \\
\text { 2013) }\end{array}$ & $\begin{array}{l}\text { Purchase: iTunes. } \\
\text { Subscription: Spotify. }\end{array}$ & $\begin{array}{l}\text { Content products / } \\
\text { services: Music. }\end{array}$ & - & $\begin{array}{l}\text { Free offerings in the market: Piracy as } \\
\text { a form of purchase substitution. }\end{array}$ & $\begin{array}{l}\text { Viability reducing: With the existing } \\
\text { business models, industry revenues are } \\
\text { declining. }\end{array}$ \\
\hline $\begin{array}{l}\text { (Casadesus- } \\
\text { Masanell and } \\
\text { Hervas-Drane } \\
\text { 2010) }\end{array}$ & $\begin{array}{l}\text { Subscription: MusicNet, Pressplay. } \\
\text { Purchase: iTunes. } \\
\text { Advertising }\end{array}$ & $\begin{array}{l}\text { Content products / } \\
\text { services: Music. }\end{array}$ & - & $\begin{array}{l}\text { Free offerings in the market: When } \\
\text { competing with a "free" good, a } \\
\text { differentiated good / service has to be } \\
\text { offered to charge customers directly. }\end{array}$ & - \\
\hline $\begin{array}{l}\text { (Casadesus- } \\
\text { Masanell and } \\
\text { Zhu 2013) }\end{array}$ & Advertising & $\begin{array}{l}\text { Content products / } \\
\text { services: E-books. } \\
\text { Software products / } \\
\text { services: Email } \\
\text { programs. }\end{array}$ & $\begin{array}{l}\text { Early and } \\
\text { mature } \\
\text { stage }\end{array}$ & $\begin{array}{l}\text { Free offerings in the market: } \\
\text { Competitors give the product / service } \\
\text { away for free and generate revenues } \\
\text { through advertising, leading to lower } \\
\text { willingness to pay. }\end{array}$ & $\begin{array}{l}\text { Viability reducing: Products and } \\
\text { services that directly charged the } \\
\text { customer (e.g. commercial email was } \\
\text { first usage based, then subscription } \\
\text { based) can no longer charge for the } \\
\text { service when a competitor introduces a } \\
\text { free version of the product / service (e.g. } \\
\text { Hotmail). } \\
\end{array}$ \\
\hline $\begin{array}{l}\text { (Casero-Ripollés } \\
\text { and Izquierdo- } \\
\text { Castillo 2013) }\end{array}$ & $\begin{array}{l}\text { Purchase: Micropayment. } \\
\text { Subscription } \\
\text { Pay-per-use: User pays per day or week of use. } \\
\text { Advertising } \\
\text { Freemium: Access to last-minute news is free, } \\
\text { but customer is charged for high value-added } \\
\text { news; or access to a limited number of articles is } \\
\text { free, but the customer has to pay when reading } \\
\text { more articles. }\end{array}$ & $\begin{array}{l}\text { Content products / } \\
\text { services: News media in } \\
\text { Spain. }\end{array}$ & $\begin{array}{l}\text { Early and } \\
\text { mature } \\
\text { stage }\end{array}$ & $\begin{array}{l}\text { Free offerings in the market: Users } \\
\text { are increasingly resistant to paying, } \\
\text { when the content is accessible without } \\
\text { payment (e.g. provided by a } \\
\text { competitor). } \\
\text { Differentiation capabilities: Digital } \\
\text { newsstands: Various players have one } \\
\text { digital access point for their } \\
\text { newspapers. }\end{array}$ & $\begin{array}{l}\text { Viability reducing: Advertising alone } \\
\text { will not be enough to generate the } \\
\text { income needed by the newspaper } \\
\text { business. } \\
\text { Viability enhancing: When offering } \\
\text { content for free, the business has to } \\
\text { focus on generating a large customer } \\
\text { base and on monetizing it through } \\
\text { advertising. }\end{array}$ \\
\hline
\end{tabular}




\begin{tabular}{|c|c|c|c|c|c|}
\hline Case/reference & Revenue mechanisms & $\begin{array}{l}\text { Type of digital } \\
\text { offering }\end{array}$ & $\begin{array}{l}\text { Stage of } \\
\text { evolution }\end{array}$ & Constraints & Viability \\
\hline $\begin{array}{l}\text { (Y.-J. Chen and } \\
\text { Seshadri 2007) }\end{array}$ & $\begin{array}{l}\text { Purchase: In the development phase a high-end } \\
\text { flagship product is offered, whereas in the } \\
\text { production / distribution phase the product is } \\
\text { degraded to offer different versions with varying } \\
\text { quality levels (e.g. high-end products with more } \\
\text { functions). }\end{array}$ & $\begin{array}{l}\text { Software products / } \\
\text { services }\end{array}$ & $\begin{array}{l}\text { Early and } \\
\text { mature } \\
\text { stage }\end{array}$ & Different willingness to pay. & $\begin{array}{l}\text { Viability reducing: When customers } \\
\text { have access to competing options, it may } \\
\text { be viability reducing for sellers to serve } \\
\text { all high-end customers. } \\
\text { Viability enhancing: Seller can increase } \\
\text { the revenue by offering different } \\
\text { versions with varying quality levels } \\
\text { (degradation is easy and inexpensive for } \\
\text { information goods). }\end{array}$ \\
\hline $\begin{array}{l}\text { (Clemons and } \\
\text { Madhani 2011) }\end{array}$ & $\begin{array}{l}\text { Advertising: Third-party payer online business } \\
\text { model (key word auction / sponsored search). In } \\
\text { the third-party payer model, the platform } \\
\text { provider offers a service to the users free of } \\
\text { charge, while charging a third party (e.g. } \\
\text { advertisers) for participation. }\end{array}$ & $\begin{array}{l}\text { Brokerage services: } \\
\text { Search engine (Google). }\end{array}$ & $\begin{array}{l}\text { Early and } \\
\text { mature } \\
\text { stage }\end{array}$ & $\begin{array}{l}\text { Willingness to pay: Customers are not } \\
\text { willing to pay for search engine service. }\end{array}$ & $\begin{array}{l}\text { Viability enhancing: Subsidization of } \\
\text { searchers by advertisers. }\end{array}$ \\
\hline (Clemons 2009) & $\begin{array}{l}\text { Purchase (e.g. micropayments for digital music, } \\
\text { accessories for virtual communities). } \\
\text { Subscription (e.g. for participating in online } \\
\text { games). } \\
\text { Advertising (e.g. music, news media). }\end{array}$ & $\begin{array}{l}\text { Many different digital } \\
\text { products / services (e.g. } \\
\text { content and experience } \\
\text { products and services). }\end{array}$ & $\begin{array}{l}\text { Early and } \\
\text { mature } \\
\text { stage }\end{array}$ & $\begin{array}{l}\text { Willingness to pay: To profit from } \\
\text { content it has to be a unique asset and } \\
\text { has to be protected from easy } \\
\text { duplication. Willingness to participate } \\
\text { increases when illegal sharing is } \\
\text { punished by litigation. } \\
\text { Lock-in: Can be created through high } \\
\text { switching costs. }\end{array}$ & $\begin{array}{l}\text { Viability reducing: Relying only on } \\
\text { advertising is not viable (advertising } \\
\text { revenues are dropping). } \\
\text { Viability enhancing: Advertising is } \\
\text { viable at the beginning; in a mature } \\
\text { phase other revenue mechanisms have to } \\
\text { be combined with it to ensure viability. }\end{array}$ \\
\hline $\begin{array}{l}\text { (Concha et al. } \\
2010)\end{array}$ & $\begin{array}{l}\text { Subscription } \\
\text { Pay-per-use: Based on resources used, number } \\
\text { of users, and periods of time (or a combination } \\
\text { of them). }\end{array}$ & $\begin{array}{l}\text { Software products / } \\
\text { services }\end{array}$ & - & $\begin{array}{l}\text { Ability to adopt new revenue } \\
\text { mechanisms: Revenue mechanisms } \\
\text { cannot be changed dynamically without } \\
\text { effort (e.g. for a revenue model based on } \\
\text { usage, the usage has to be measurable). }\end{array}$ & - \\
\hline (Currie 2004) & $\begin{array}{l}\text { Subscription / Pay-per-use: Software } \\
\text { applications with revenues on a pay-per-seat } \\
\text { basis. }\end{array}$ & $\begin{array}{l}\text { Software products / } \\
\text { services }\end{array}$ & - & - & - \\
\hline $\begin{array}{l}\text { (Currie et al. } \\
\text { 2007) }\end{array}$ & $\begin{array}{l}\text { Purchase } \\
\text { Subscription } \\
\text { Pay-per-use }\end{array}$ & $\begin{array}{l}\text { Software and } \\
\text { computing products / } \\
\text { services }\end{array}$ & $\begin{array}{l}\text { Early and } \\
\text { mature } \\
\text { stage }\end{array}$ & $\begin{array}{l}\text { Ability to adopt new revenue } \\
\text { mechanisms: The pay-per-use } \\
\text { alternative leads to a rejection of the } \\
\text { purchase revenue mechanism (as } \\
\text { customers like to reduce their cost of } \\
\text { ownership). } \\
\text { Differentiation capabilities Confidence } \\
\text { in provider. }\end{array}$ & $\begin{array}{l}\text { Viability enhancing: Confidence in } \\
\text { provider through his longevity. }\end{array}$ \\
\hline
\end{tabular}




\begin{tabular}{|c|c|c|c|c|c|}
\hline Case/reference & Revenue mechanisms & $\begin{array}{l}\text { Type of digital } \\
\text { offering }\end{array}$ & \begin{tabular}{|l|} 
Stage of \\
evolution
\end{tabular} & Constraints & Viability \\
\hline (Das et al. 2011) & $\begin{array}{l}\text { Purchase / Subscription: Spot market with } \\
\text { dynamic prices and forward contracts. }\end{array}$ & $\begin{array}{l}\text { Computing products / } \\
\text { services: Online storage } \\
\text { service provider (e.g. } \\
\text { Amazon S3). }\end{array}$ & \begin{tabular}{|l|} 
Early and \\
mature \\
stage
\end{tabular} & $\begin{array}{l}\text { Information asymmetry: Uncertain } \\
\text { demands / willingness to pay. }\end{array}$ & $\begin{array}{l}\text { Viability reducing: With no forward } \\
\text { contracts, the provider bears the full risk } \\
\text { related to a fluctuation in demand. } \\
\text { Viability enhancing: Forward contracts } \\
\text { transfer the risk from sellers to buyers; } \\
\text { revenue is maximized. }\end{array}$ \\
\hline $\begin{array}{l}\text { (Deodhar et al. } \\
\text { 2012) }\end{array}$ & $\begin{array}{l}\text { Purchase: Purchase of software license with } \\
\text { and without access to source code. } \\
\text { Freemium: One free / community product, one } \\
\text { enterprise edition (revenues through enterprise } \\
\text { edition with enhanced functionality and } \\
\text { support). }\end{array}$ & $\begin{array}{l}\text { Software products / } \\
\text { services }\end{array}$ & $\begin{array}{l}\text { Early and } \\
\text { mature } \\
\text { stage }\end{array}$ & $\begin{array}{l}\text { Differentiation capabilities: Maintain a } \\
\text { sufficient distinction between free and } \\
\text { enterprise version. }\end{array}$ & $\begin{array}{l}\text { Viability enhancing: The purpose of the } \\
\text { free version is to increase distribution } \\
\text { (important in the early phase of business } \\
\text { model evolution); the purpose of the } \\
\text { enterprise edition is to create revenues. }\end{array}$ \\
\hline $\begin{array}{l}\text { (Desai and } \\
\text { Currie 2005) }\end{array}$ & $\begin{array}{l}\text { Purchase (e.g. Intercea). } \\
\text { Subscription / Pay-per-use: For hosted } \\
\text { applications (e.g. Salesforce; Fullard Learning). }\end{array}$ & \begin{tabular}{|l|} 
Software and \\
computing products / \\
services
\end{tabular} & - & $\begin{array}{l}\text { Lock-in: Customers are reluctant to be } \\
\text { locked in long term contracts. }\end{array}$ & - \\
\hline $\begin{array}{l}\text { (Dewan et al. } \\
\text { 2003) }\end{array}$ & Advertising & $\begin{array}{l}\text { Content products / } \\
\text { services: E.g. news and } \\
\text { entertainment. } \\
\text { Brokerage services: } \\
\text { E.g. search engines. }\end{array}$ & $\begin{array}{l}\text { Early and } \\
\text { mature } \\
\text { stage }\end{array}$ & $\begin{array}{l}\text { Willingness to pay: Advertising } \\
\text { reduces the attractiveness of a website } \\
\text { (it is the content that attracts customers). }\end{array}$ & $\begin{array}{l}\text { Viability reducing: Using too much } \\
\text { advertising in an early phase. } \\
\text { Viability enhancing: Overinvest in } \\
\text { content in the beginning; after a } \\
\text { viewership is established, the investment } \\
\text { is compensated by higher advertising } \\
\text { rates in a mature phase. }\end{array}$ \\
\hline $\begin{array}{l}\text { (Feng et al. } \\
2009 \text { ) }\end{array}$ & $\begin{array}{l}\text { Purchase: Digital product seller / copyright } \\
\text { owner sells directly to customers through an } \\
\text { online B2C channel. } \\
\text { Also indirect purchase: Dual channel model } \\
\text { where the seller allows consumers, who have } \\
\text { already bought the product through the B2C } \\
\text { channel, to legally resell the product to other } \\
\text { consumers (C2C) while sharing the revenue } \\
\text { with the seller. }\end{array}$ & $\begin{array}{l}\text { Content products / } \\
\text { services: Music, videos, } \\
\text { e-books. } \\
\text { Software products / } \\
\text { services }\end{array}$ & $\begin{array}{l}\text { Early and } \\
\text { mature } \\
\text { stage }\end{array}$ & $\begin{array}{l}\text { Low willingness to pay. } \\
\text { Differentiation capabilities: Incentive } \\
\text { for consumers to purchase and } \\
\text { legitimately distribute digital content. } \\
\text { Enablement: Digital rights management } \\
\text { (DRM) technology. }\end{array}$ & $\begin{array}{l}\text { Viability enhancing: Having both the } \\
\mathrm{B} 2 \mathrm{C} \text { and } \mathrm{C} 2 \mathrm{C} \text { channel is revenue } \\
\text { maximizing. }\end{array}$ \\
\hline
\end{tabular}




\begin{tabular}{|c|c|c|c|c|c|}
\hline Case/reference & Revenue mechanisms & $\begin{array}{l}\text { Type of digital } \\
\text { offering }\end{array}$ & $\begin{array}{l}\text { Stage of } \\
\text { evolution }\end{array}$ & Constraints & Viability \\
\hline $\begin{array}{l}\text { (Günzel and } \\
\text { Holm 2013) }\end{array}$ & $\begin{array}{l}\text { Subscription: E.g. monthly payment through } \\
\text { iPhone app. } \\
\text { Advertising }\end{array}$ & $\begin{array}{l}\text { Content products / } \\
\text { services: Leading } \\
\text { Danish newspapers. }\end{array}$ & \begin{tabular}{|l|} 
Early and \\
mature \\
stage
\end{tabular} & $\begin{array}{l}\text { Ability to adopt new revenue } \\
\text { mechanisms: Online advertising cannot } \\
\text { cover the costs for content production. }\end{array}$ & $\begin{array}{l}\text { Viability reducing: Inability to } \\
\text { monetize customer base. } \\
\text { Viability enhancing: Being present on } \\
\text { all new media platforms increased the } \\
\text { newspaper's readership. } \\
\text { Newspapers need a mix of revenue } \\
\text { models (selection and evolution in the } \\
\text { front-end of the business model through } \\
\text { trial-and-error). } \\
\text { Separation of access to paid and unpaid } \\
\text { content. }\end{array}$ \\
\hline $\begin{array}{l}\text { (Hinz and Spann } \\
\text { 2008) }\end{array}$ & $\begin{array}{l}\text { Purchase: Secret reserve price auctions over a } \\
\text { period of time, each with the same secret } \\
\text { reserve price. In each auction, only one potential } \\
\text { buyer can place one bid. }\end{array}$ & $\begin{array}{l}\text { Experience goods: } \\
\text { Virtual worlds. }\end{array}$ & $\begin{array}{l}\text { Early and } \\
\text { mature } \\
\text { stage }\end{array}$ & $\begin{array}{l}\text { Willingness to pay: Ability of } \\
\text { information diffusion in a social } \\
\text { network increases willingness to pay. }\end{array}$ & $\begin{array}{l}\text { Viability enhancing: Information } \\
\text { diffusion leads to higher revenues. }\end{array}$ \\
\hline $\begin{array}{l}\text { (Hinz et al. } \\
2011)\end{array}$ & $\begin{array}{l}\text { Purchase: Name-your-own-price (dynamic } \\
\text { pricing) with a fixed threshold or adaptive } \\
\text { threshold price (price policy revealed or not to } \\
\text { the public). }\end{array}$ & $\begin{array}{l}\text { Software products / } \\
\text { services }\end{array}$ & - & - & $\begin{array}{l}\text { Viability enhancing: Provider's profits } \\
\text { and customer satisfaction are highest } \\
\text { with an adaptive threshold price that is } \\
\text { revealed to the customer. }\end{array}$ \\
\hline (Hu et al. 2004) & $\begin{array}{l}\text { Brokerage fee: Online escrow service provider. } \\
\text { Online auction (financial handling): Buyer } \\
\text { sends money to the online escrow service } \\
\text { provider, who informs the seller to ship the } \\
\text { merchandise; after satisfaction confirmation of } \\
\text { the buyer, the money is transferred to the seller. } \\
\text { Escrow fees are usually based on the transaction } \\
\text { value (purchase price) as well as on the method } \\
\text { of payment. The escrow fee can be paid by the } \\
\text { seller, the buyer, or by both of them. }\end{array}$ & Brokerage services & $\begin{array}{l}\begin{array}{l}\text { Mature } \\
\text { stage }\end{array} \\
\end{array}$ & $\begin{array}{l}\text { Information asymmetry leads to lack } \\
\text { of trust. }\end{array}$ & $\begin{array}{l}\text { Viability reducing: When the fee is too } \\
\text { high it leads to a low acceptance and } \\
\text { thereby to a decrease in sales and } \\
\text { revenues. When the fee is too low, the } \\
\text { acceptance is high but not enough } \\
\text { revenue can be generated. } \\
\text { Viability enhancing: Service bypasses } \\
\text { asymmetric information. }\end{array}$ \\
\hline $\begin{array}{l}\text { (Kerrigan and } \\
\text { Graham 2010) }\end{array}$ & $\begin{array}{l}\text { Purchase } \\
\text { Advertising }\end{array}$ & $\begin{array}{l}\text { Content products / } \\
\text { services: Regional news } \\
\text { media. }\end{array}$ & - & $\begin{array}{l}\text { Willingness to pay: Consumers, } \\
\text { especially the younger 'digital natives', } \\
\text { are unwilling to pay for news. } \\
\text { Differentiation capabilities }\end{array}$ & $\begin{array}{l}\text { Value enhancing: Aggressively channel } \\
\text { readers to websites to generate online } \\
\text { advertising revenues. } \\
\text { Offering highly specialized content (e.g. } \\
\text { with a focus on finance) to consumers } \\
\text { for a fee together with conventional } \\
\text { news that are free of charge. }\end{array}$ \\
\hline $\begin{array}{l}\text { (Khanagha et al. } \\
\text { 2014) }\end{array}$ & Pay-per-use & $\begin{array}{l}\text { Software and } \\
\text { computing products / } \\
\text { services: Cloud services. }\end{array}$ & - & $\begin{array}{l}\text { Willingness to pay: Regarding cloud } \\
\text { services, customers are only willing to } \\
\text { pay for the service they use. }\end{array}$ & - \\
\hline
\end{tabular}




\begin{tabular}{|c|c|c|c|c|c|}
\hline Case/reference & Revenue mechanisms & $\begin{array}{l}\text { Type of digital } \\
\text { offering }\end{array}$ & $\begin{array}{l}\text { Stage of } \\
\text { evolution }\end{array}$ & Constraints & Viability \\
\hline $\begin{array}{l}\text { (Kim and Ahn } \\
\text { 2007) }\end{array}$ & $\begin{array}{l}\text { Brokerage fee: E-marketplace / broker- } \\
\text { managed online market where the market maker } \\
\text { extracts fees for the transactions occurring on } \\
\text { the e-marketplace (from the seller). }\end{array}$ & Brokerage services & $\begin{array}{l}\text { Early and } \\
\text { mature } \\
\text { stage }\end{array}$ & $\begin{array}{l}\text { Information asymmetry leads to lack } \\
\text { of trust especially on the buyers' side as } \\
\text { they are at greater risk of being } \\
\text { exploited. }\end{array}$ & $\begin{array}{l}\text { Viability enhancing: Over time, market } \\
\text { makers can generate trust through } \\
\text { customers' good experience. }\end{array}$ \\
\hline $\begin{array}{l}\text { (Krishnan et al. } \\
2007)\end{array}$ & $\begin{array}{l}\text { Subscription: Membership fee. } \\
\text { Pay-per-use } \\
\text { Purchase: Micropayment. }\end{array}$ & $\begin{array}{l}\text { Content products / } \\
\text { services: Peer-to-Peer } \\
\text { (P2P) services. }\end{array}$ & - & - & - \\
\hline $\begin{array}{l}\text { (Krueger and } \\
\text { Swatman 2004) }\end{array}$ & $\begin{array}{l}\text { Purchase: Charge for archived news, special } \\
\text { services, or indirectly through merchandise. } \\
\text { Pay-per-use } \\
\text { Subscription } \\
\text { Advertising }\end{array}$ & $\begin{array}{l}\text { Content products / } \\
\text { services: Regional } \\
\text { online newspaper. }\end{array}$ & $\begin{array}{l}\text { Early and } \\
\text { mature } \\
\text { stage }\end{array}$ & $\begin{array}{l}\text { Free offerings in the market: Free } \\
\text { content offerings are dominating. } \\
\text { Ability to adopt new revenue } \\
\text { mechanisms: Image prohibits } \\
\text { newspaper form selling customer data. }\end{array}$ & - \\
\hline (Laffey 2010) & $\begin{array}{l}\text { Advertising } \\
\text { Brokerage fees }\end{array}$ & $\begin{array}{l}\text { Brokerage services: } \\
\text { Comparison websites } \\
\text { providing a matching } \\
\text { function between } \\
\text { buyers and sellers. }\end{array}$ & - & Willingness to pay; lock-in & $\begin{array}{l}\text { Viability enhancing: Increasing } \\
\text { switching costs and lock-in through } \\
\text { loyalty programs, dominant designs, } \\
\text { trust, and customization. } \\
\text { Subsidization of customers (no } \\
\text { comparison website charges the buyer). }\end{array}$ \\
\hline (Lin et al. 2011) & $\begin{array}{l}\text { Brokerage fee: Two-sided platform (buyer and } \\
\text { seller pay an access fee to the platform owner). }\end{array}$ & $\begin{array}{l}\text { Brokerage services: } \\
\text { E.g. app store. }\end{array}$ & - & Low willingness to pay. & $\begin{array}{l}\text { Viability enhancing: Charging a high } \\
\text { access fee on the sellers' side and } \\
\text { thereby subsidizing the buyers' fee leads } \\
\text { to optimal revenues. }\end{array}$ \\
\hline (Lin et al. 2012) & $\begin{array}{l}\text { Advertising: Ad-supported and mixed (ad-free } \\
\text { and ad-supported) business models. } \\
\text { Two types of ad revenue model: Cost-per-mille } \\
\text { (CPM) charges advertisers on the basis of } \\
\text { exposure and performance based model (e.g. } \\
\text { cost per click) charge advertisers on the basis of } \\
\text { user actions. } \\
\text { Subscription: Ad-free and mixed business } \\
\text { models. }\end{array}$ & $\begin{array}{l}\text { Content products / } \\
\text { services }\end{array}$ & - & $\begin{array}{l}\text { Ability to adopt new revenue } \\
\text { mechanisms: Ad-averse customers do } \\
\text { not participate in ad-supported services. }\end{array}$ & $\begin{array}{l}\text { Viability enhancing: Offering both the } \\
\text { ad-supported and ad-free services, } \\
\text { whereas the ad-supported service should } \\
\text { be free of charge for the user to increase } \\
\text { revenues. }\end{array}$ \\
\hline (Liu et al. 2010) & $\begin{array}{l}\text { Advertising: Keyword auction to allocate } \\
\text { advertising slots. } \\
\text { Pay for performance / outcome based pricing } \\
\text { (incl. pay per click / purchase / call); } \\
\text { introduction of minimum bids and valuation per } \\
\text { click is weighted with expected CTR (click } \\
\text { through rate). } \\
\text { Winners of keyword auction are charged for } \\
\text { their realized clicks at unit prices they bid } \\
\text { (weighted unit price auction). }\end{array}$ & $\begin{array}{l}\text { Brokerage services: } \\
\text { E.g. search engine. } \\
\text { Software products / } \\
\text { services: E.g. email } \\
\text { programs. }\end{array}$ & $\begin{array}{l}\text { Early and } \\
\text { mature } \\
\text { stage }\end{array}$ & $\begin{array}{l}\text { Information asymmetry: Lack of } \\
\text { knowledge on bidders' outcome } \\
\text { generating potential. }\end{array}$ & $\begin{array}{l}\text { Viability enhancing: In an early phase, } \\
\text { fixed payment for advertising exposure } \\
\text { or performance based payment with } \\
\text { minimum bids that attract advertisers is } \\
\text { viable. After ex-ante information on } \\
\text { bidders' outcome-generating potential is } \\
\text { available, revenue can be maximized by } \\
\text { weighting unit prices. }\end{array}$ \\
\hline
\end{tabular}




\begin{tabular}{|c|c|c|c|c|c|}
\hline Case/reference & Revenue mechanisms & $\begin{array}{l}\text { Type of digital } \\
\text { offering }\end{array}$ & \begin{tabular}{|l|}
$\begin{array}{l}\text { Stage of } \\
\text { evolution }\end{array}$ \\
\end{tabular} & Constraints & Viability \\
\hline $\begin{array}{l}\text { (Oestreicher- } \\
\text { Singer and } \\
\text { Zalmanson 2013) }\end{array}$ & $\begin{array}{l}\text { Freemium: The basic use of Last.fm is free of } \\
\text { charge, whereas premium services are offered } \\
\text { for a fixed monthly subscription fee. }\end{array}$ & $\begin{array}{l}\text { Content products / } \\
\text { services: Music. } \\
\text { Experience products / } \\
\text { services: Virtual } \\
\text { community. } \\
\end{array}$ & $\begin{array}{l}\text { Early and } \\
\text { mature } \\
\text { stage }\end{array}$ & $\begin{array}{l}\text { Willingness to pay } \\
\text { Differentiation capabilities/ lock-in: } \\
\text { Unique service combination. }\end{array}$ & $\begin{array}{l}\text { Viability enhancing: Through the } \\
\text { combination with a virtual community, } \\
\text { the free to fee conversion rate is } \\
\text { increased and revenue is maximized. }\end{array}$ \\
\hline $\begin{array}{l}\text { (Papies et al. } \\
\text { 2011) }\end{array}$ & $\begin{array}{l}\text { Purchase: E.g. iTunes. } \\
\text { Subscription: Unlimited access to an online } \\
\text { library of titles, but the access as well as the } \\
\text { usability of the titles is restricted to the period of } \\
\text { membership (e.g. Napster 2.0). } \\
\text { Advertising: E.g. Spotify or We } 7 \text {. }\end{array}$ & $\begin{array}{l}\text { Content products / } \\
\text { services: Music. }\end{array}$ & $\begin{array}{l}\text { Early and } \\
\text { mature } \\
\text { stage }\end{array}$ & $\begin{array}{l}\text { Willingness to pay: Customers might } \\
\text { be excluded from participation because } \\
\text { of download restrictions through DRM. }\end{array}$ & $\begin{array}{l}\text { Viability reducing: Subscription model } \\
\text { is not attractive. } \\
\\
\text { Viability enhancing The advertising- } \\
\text { based model might attract new } \\
\text { customers. Free, ad-funded downloads } \\
\text { could maximize market size when the } \\
\text { risk of cannibalization is low. } \\
\text { The purchase model might be the } \\
\text { dominating model for music downloads. }\end{array}$ \\
\hline (Roquilly 2011) & $\begin{array}{l}\text { Purchase: Box-to-play (user pays only to install } \\
\text { the program but incurs no monthly charges); } \\
\text { online platforms for trading virtual property } \\
\text { (sometimes auction based). } \\
\text { Freemium: Free-to-play (free, but users must } \\
\text { pay for a premium version of the program or for } \\
\text { virtual items). } \\
\text { Subscription: Pay-to-play (with monthly fee). }\end{array}$ & $\begin{array}{l}\text { Experience products / } \\
\text { services: Online } \\
\text { gaming. }\end{array}$ & $\begin{array}{l}\text { Early and } \\
\text { mature } \\
\text { stage }\end{array}$ & Lock-in & $\begin{array}{l}\text { Viability enhancing: Choosing free-to- } \\
\text { play increases user numbers (especially } \\
\text { important in an early phase of the } \\
\text { business model). With a high lock-in } \\
\text { effect, pay-to-play is revenue } \\
\text { maximizing (e.g. World of Warcraft). }\end{array}$ \\
\hline $\begin{array}{l}\text { (Williams et al. } \\
\text { 2008) }\end{array}$ & $\begin{array}{l}\text { Purchase: Micropricing per song (iTunes). } \\
\text { Also indirect purchase: two sites link each other } \\
\text { and the resultant revenues are shared } \\
\text { (Myspace.com). } \\
\text { Subscription: Premium subscription fee for } \\
\text { providing premium services (salesforce.com). }\end{array}$ & $\begin{array}{l}\text { Content products / } \\
\text { services: iTunes. } \\
\text { Software products / } \\
\text { services: Salesfore.com. } \\
\text { Experience products / } \\
\text { services: Myspace.com. }\end{array}$ & - & $\begin{array}{l}\text { Ability to adopt new revenue } \\
\text { mechanisms: Digitization leads to } \\
\text { income sources besides the direct } \\
\text { customers. }\end{array}$ & - \\
\hline $\begin{array}{l}\text { (Wu and Banker } \\
\text { 2010) }\end{array}$ & $\begin{array}{l}\text { Advertising } \\
\text { Subscription / Pay-per-use: Flat fee pricing, } \\
\text { usage-based pricing, and two-part tariff pricing } \\
\text { (combination of usage-based pricing and } \\
\text { subscription fee). }\end{array}$ & $\begin{array}{l}\text { Experience products / } \\
\text { services: Facebook, } \\
\text { Twitter, Myspace, } \\
\text { SecondLife. }\end{array}$ & $\begin{array}{l}\text { Early and } \\
\text { mature } \\
\text { stage }\end{array}$ & $\begin{array}{l}\text { Different willingness to pay (in } \\
\text { combination with different levels of } \\
\text { usage and monitoring cost). } \\
\text { Lock-in }\end{array}$ & $\begin{array}{l}\text { Viability enhancing: In the early stage, } \\
\text { the service is provided for free to the } \\
\text { customers (attract traffic to be viable). In } \\
\text { a later stage, when lock-in is created, } \\
\text { they can charge their users directly (e.g. } \\
\text { Twitter Japan). Two-part tariff pricing is } \\
\text { revenue maximizing when customers } \\
\text { have different consumption levels and } \\
\text { monitoring costs are near zero. With } \\
\text { monitoring costs, flat fee pricing is } \\
\text { dominating. }\end{array}$ \\
\hline
\end{tabular}

